\title{
'It is the theatre of great felicity to a number of people': Bentham at Ford Abbey ${ }^{1}$
}

CATHERINE FULLER

\author{
Bentham Project, University College London
}

\section{Preface}

Critics express surprise that Bentham was a man capable of any emotional depth, of experiencing pleasure, or of expressing sympathy. Himmelfarb, for example, believed that Bentham's decision to abandon the plan for solitary cells in the Panopticon prison was prompted by concern with expense rather than a 'newly aroused sense of compassion', ${ }^{2}$ and that his exhortation to gratification of the palate sat 'oddly from one of Bentham's puritanical bent'. ${ }^{3}$ An introduction to a recent edition of Dickens' Hard Times, refers to Bentham's 'undernourished conception of human nature'. 4 Such criticisms undoubtedly, and the latter explicitly, take their lead from John Stuart Mill himself who wrote of Bentham: 'In many of the most natural and strongest feelings of human nature he had no sympathy; from many of its graver experiences he was altogether cut off. ${ }^{5}$ Bentham's own description of his home at Queen Square Place as a hermitage is often taken to mean he saw few people, ate little, and was ill at ease in company. ${ }^{6}$ Mack, for example, identifies Bentham's life as having a 'tranquil, methodical, semi-monastic routine'. ${ }^{7}$ Descriptions of meetings with Bentham that

\footnotetext{
${ }^{1}$ For Bentham on Ford Abbey, see The Works of Jeremy Bentham, ed. J. Bowring, 11 vols., Edinburgh, 1843 , x. p. 487.

I would like to thank my colleagues Dr Michael Quinn, Professor Fred Rosen, and Professor Philip Schofield for their meticulous, helpful, and encouraging comments on drafts of this essay. Professor Rosen has written in depth about Bentham's work at Ford Abbey in 'From Jeremy Bentham's Radical Philosophy to J.S. Mill's Philosophic Radicalism' to be published in the forthcoming Cambridge Nineteenth Century History of Political Thought.

${ }^{2}$ G. Himmelfarb, Victorian Minds, London, 1968, p.46.

${ }^{3}$ Ibid., 53-4.

${ }^{4}$ Charles Dickens, Hard Times. For These Times, ed. G. Smith, London, 1994, p. 317.

${ }^{5}$ See John Stuart Mill's essay on Bentham, first published in 1838, reprinted in Essays on Ethics, Religion and Society, ed. J. M. Robson, F. E. L. Priestley, D. P. Dryer, Toronto, 1969 (Collected Works of J.S. Mill, vol. x), p.91. Hereafter (CWJSM).

${ }^{6}$ For Bentham's description of his home as a hermitage, and the ironic description of his food as potatoes and water, see, for example, Letter 2972 to John Adams Smith, dated 29 May 1823, The Correspondence of Jeremy Bentham, vol. xi., ed. Catherine Fuller, Oxford, 2000, pp. 236-7 (hereafter Correspondence $(C W)$. Such descriptions were taken up by his acquaintances, see, for example, Letter 2931, dated 15 October 1822, Correspondence $(C W)$, xi. p. 165, and W. Hazlitt, The Spirit of the Age: or, Contemporary Portraits, [1825], Collected Works of William Hazlitt, 21 vols., London, 1932 xi. p. 6: 'like an anchoret in his cell'.

${ }^{7}$ M. Mack, Jeremy Bentham. An Odyssey of Ideas, London, 1962, p. 335.
} 
survive bear witness to Bentham's eccentricities, but not to his lack of compassion (or indeed disregard for food). ${ }^{8}$ Whilst not denying that there is more than a grain of truth in the views of Mill and others, the evidence we have of Bentham's time at Ford Abbey allows us to trace from accounts of friends, employees, and Bentham himself, a period in the life of a man, aged 66 to 70, who is eager to please, capable of strong and lasting affections, and has a keen perception of what happiness is.

\section{Introduction}

One of the biggest disappointments of Bentham's life was probably the failure of the government to adopt his scheme to build a Panopticon prison at Millbank in London. The scheme, first developed in 1786-7 while Bentham was visiting his brother Samuel who was working in Russia, led to the publication of Panopticon, or the Inspection-House in 1791. In the same year Bentham's idea to build such a prison in London, and to be both contractor and manager thereof, was taken up by William Pitt, then First Lord of the Treasury. The scheme occupied much of Bentham's time and energy, but eventually in 1812 the Government, unable to overcome a growing number of obstacles, abandoned all plans to build the Panopticon prison. It was a bitter blow to Bentham, and a disappointment to which he referred intermittently during the remaining twenty years of his life. ${ }^{9}$ However the $£ 23,000$ he received in compensation from the Government in 1813 , allowed Bentham the luxury of finding a country retreat. ${ }^{10}$ Thus out of disappointment came an opportunity for pleasure, relaxation, and a congenial environment in which to continue to write.

While maintaining a home in London, Bentham had from 1788 rented an apartment in a farm at Dollis Hill, in Hendon, North London to which he retired periodically to write, and from 1806 he had spent some of each year at Barrow Green

\footnotetext{
${ }^{8}$ e.g. John Neal, Preface to J. Bentham, Introduction of Principles of Legislation, ed. E. Dumont and trans. J. Neal, Boston, 1830. Richard Rush (1780-1869) who visited Bentham while American Minister in London 1817-25, A Residence at the Court of London, [1833], London, 1987, as index. Hazlitt, The Spirit of the Age, xi. esp. 6; Archibald Prentice, 'Some recollections of Jeremy Bentham', Manchester Central Reference Library, Historical Tracts Collection No. H69/3, 1837.

${ }^{9}$ See for example, Letter 2882, 17 May 1822, Correspondence (CW), xi. pp. 79-80.

${ }^{10}$ While at Ford Abbey Bentham kept up a correspondence with other organizations that had an interest in the panopticon scheme in Manchester and Bristol, but nothing came of them. See for example Letter 2303, 20 December 1814, from W. D. Evans, a magistrate in Manchester, Correspondence (CW), ed. S. Conway, Oxford, 1988, viii. p. 442, and Letter 2345, 26 May 1816, pp. 524-5.
} 
House, Oxted, Surrey. ${ }^{11}$ But these residences did not have the grandeur and splendour of Ford Abbey, and Bentham himself referred to the house at Barrow Green as a doghole compared to it. ${ }^{12}$ Bentham rented Ford Abbey in Devon as his country residence for a period of four years, and lived at the Abbey for four extended periods of time: from 17 July 1814 until mid-March 1815; from 6 July 1815 until January 1816; from 26 July 1816 until January 1817; and finally from 31 July 1817 until February 1818. During these four years therefore Bentham spent at least half of each year at the Abbey.

Famously parsimonious in his invitations to his home at Queen Square Place in London, usually inviting one guest at a time and only after 6pm, Ford Abbey gave Bentham the opportunity and space to invite old friends and some new acquaintances to visit him. Among those who spent time at Ford Abbey were his brother Samuel and his family, (although I think it was a matter of intense regret to Bentham that his brother came to the Abbey only once in 1814 before leaving with his family for France where they settled until 1827), Francis Horner, Joseph Hume, James Mill and his growing family (fellow residents on each visit), Francis Place with his daughter Annie, David Ricardo, Sir Samuel and Lady Anne Romilly with their daughter Sophie, Jean Baptiste Say, and Edward Wakefield, nearly all of whom wrote some kind of report of their time there. ${ }^{13}$ Hence a rich record of life at Ford Abbey and of the surrounding countryside can be found not only in Bentham's correspondence, but also in the letters and journals of Bentham's visitors.

Originally founded in the twelfth century, Ford Abbey was the home of a Cistercian order for four hundred years. During this time the Abbey flourished, gained a reputation as a place of learning, and developed a properous agricultural community, all of which ceased at the dissolution of the monasteries in 1539. After a hundred

\footnotetext{
${ }^{11}$ John Heide Koe (1777-1842), Bentham's amanuensis from 1795-6, had in December 1806 married Susannah Chicheley Falkner, née Plowdern (1739-1825), who owned Barrow Green House.

${ }^{12}$ Letter 2337 to Aaron Burr, 23 February 1816, Correspondence $(C W)$, viii. 510.

${ }^{13}$ Sir Samuel Bentham (1757-1831), Lady Mary Sophia Bentham née Fordyce (1765-1858) and their children Mary Louisa (1797-1865), Samuel (1798-1816), George (1800-84), Clara (1802-29), Sarah Jane (1804-64). Francis Horner (1778-1817), MP 1806-17, and barrister who practised on the western circuit. Joseph Hume (1777-1855), radical politician. James Mill (1773-1836), Harriet Mill née Barrow (c.1782-1854), and their children John Stuart (1806-73), Wilhelmina Forbes (1808-61), Clara Esther (1810-86), Harriet Isabella (1812-c.97), James Bentham (1814-62), and Jane Stuart (1816?-83). Francis Place (1771-1854), master tailor and radical politician, and Annie (b. 1796), his daughter. David Ricardo (1772-1823), economist. Sir Samuel Romilly (1757-1818), law reformer, former Solicitor-General and MP 1806-18, his wife Lady Anne Romilly (1773-1818), and Sophie, their daughter. Jean Baptiste Say (1767-1832), French political economist. Edward Wakefield (1774-1854), philanthropist.
} 
years of absentee owners, in 1649, in the same year as he became Cromwell's Attorney General, Edmund Prideaux bought the Abbey, and undertook extensive work on the property. In 1814 the Abbey was owned by one of Prideaux's descendants John Fraunceis Gwyn, with whom Bentham negotiated his lease. ${ }^{14}$ The layout of rooms and areas available for use by Bentham are clearly marked on a plan of the Abbey sent by Francis Place to his wife Elizabeth (Figure 1). ${ }^{15}$

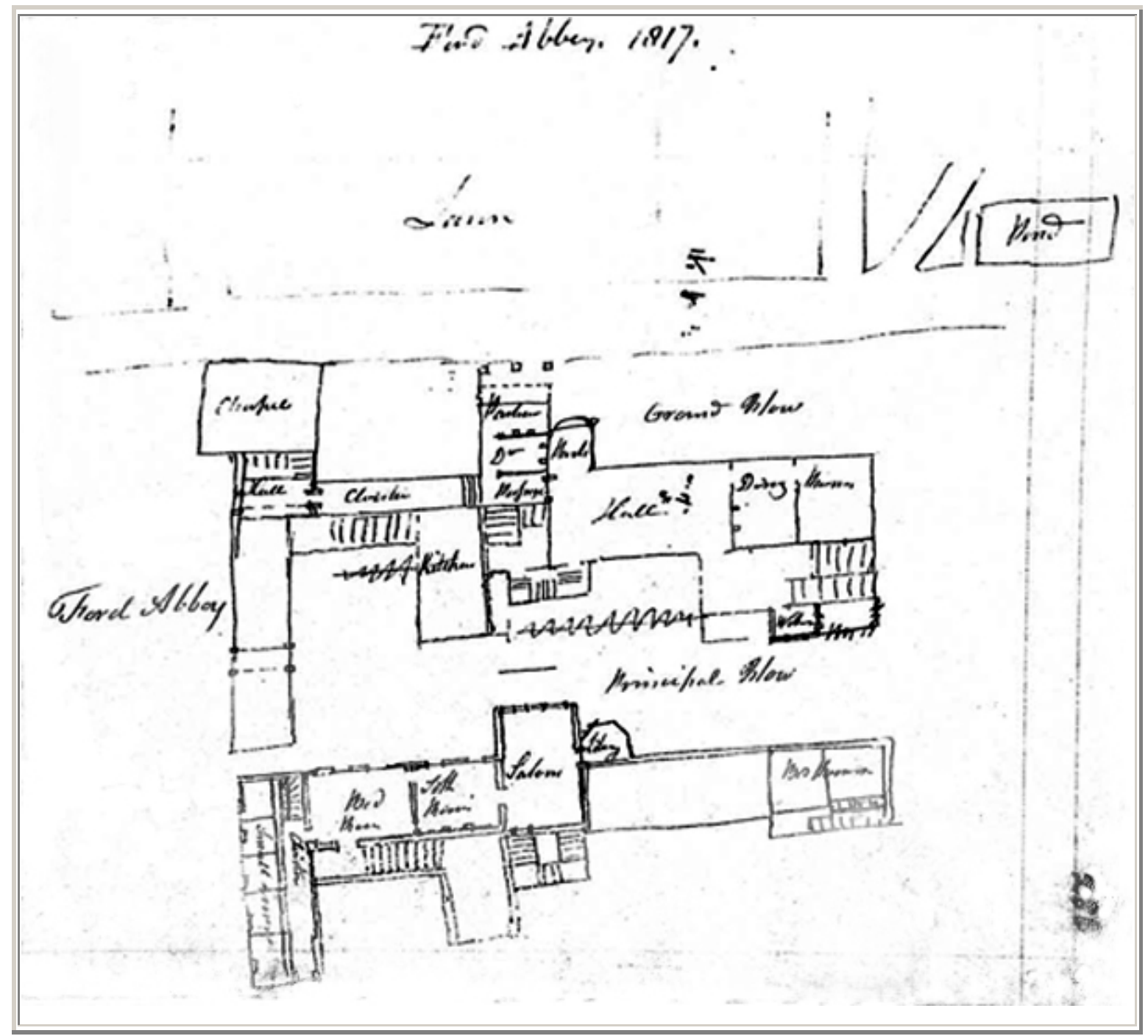

Figure 1. Ford Abbey 1817

The Abbey's size and splendour surprised and delighted all the visitors: Lady Romilly considered it a 'most picturesque and magnificent place [...] [T] he front of the building is 250 feet in length, and the inside of it fitted up with tapestry, oak

\footnotetext{
${ }^{14}$ John Fraunceis Gwyn (1761-1846), his first wife Elizabeth had died in 1807, Bentham met his second wife, Dinah, who died in 1831.
} 
wainscoting and chairs that serve to recline your head upon without stooping, ${ }^{16}$ Francis Place, who joined Bentham for some months in 1817, wrote to his wife: 'My bedroom four times as large as our dining room, proportionally high with three immense windows for a room, looking on the bowling green, the park and hills beyond, with a south eastern aspect, is really delightful. The bed is an old fashioned four post, with crimson velvet curtains lined with crimson silk'. ${ }^{17}$ John Stuart Mill, aged 8 , wrote to his maternal grandmother:

There is a little hall and a long cloister, which are reckoned very fine architecture, from the door, and likewise two beautiful rooms, a diningparlour and a breakfast-parlour adorned with fine drawings within one door; on another side is a large hall, adorned with a gilt ceiling; and beyond it two other rooms, a dining and drawing-room, of which the former contains various kinds of musical instruments, and the other is hung with beautiful tapestry. ${ }^{18}$

On his arrival Bentham wrote to his brother about the Abbey, and singled out the tapestries for special mention: 'Salloon, 60 feet long or thereabouts with copies of five of Raphael's Cartoons in Tapestry: [...] I never saw any in which to my unlearned eye the figures seemed more like human'. But Bentham's attention soon moved to the grounds: 'Gravel walk running parallel to the front of the House [...] water, stationary or running: some of it making a noise in little waterfalls running over rocky stones or artificial steps[,] bowling green with slope over slope rising above it' ${ }^{19}$

Situated alongside the River Axe, in what was then Devon, but is now Dorset, the landscape also charmed Bentham's visitors, most of whom were chiefly resident in London. James Mill wrote to Ricardo: 'It stands upon the river Axe, at the very bottom of a tolerably pretty valley, surrounded with hills of the Devonshire breed, of gentle ascent and moderate altitude, and rather too much than too little covered with

\footnotetext{
${ }^{15}$ Place Papers, British Library Add. MS 35,143 fo.286.

${ }^{16}$ Letter to Maria Edgeworth, 6 October 1817, Romilly-Edgeworth Letters, ed. S. H. Romilly, London, 1936, p. 174-5.

${ }^{17}$ Place Papers, British Library Add. MS 35,143 fo. 282.

${ }^{18}$ The Earlier Letters of John Stuart Mill 1812-1848, ed. F. E. Mineka, Toronto, 1963 (CWJSM, vol. xii), p. 4.

${ }^{19}$ Letter 2283, to Samuel Bentham, 19 July 1814, Correspondence (CW), viii. pp. 404-5.
} 
wood' ${ }^{20}$ Francis Horner, MP, judge on the western circuit, and early visitor to the Abbey in 1814, wrote to his sister that the Abbey lay 'secluded in very green meadows $;{ }^{21}$ Walter Coulson, a former amanuensis of Bentham wrote to his father in 1815:

The monks—-knowing dogs—had seated [the Abbey] in a rich valley along which flows a pleasant stream-I sauntered down to it over a sunny declivity—\& passed a river near which stood some Abele trees [white poplars] — such as you have never seen—the height of their base trunks is prodigious. I should think not much short of 100 feet. $^{22}$

Bentham himself wrote: 'Nobody that could stay here would go from hence. Nobody is so well anywhere else as everybody is here'. ${ }^{23}$

\section{Visitors}

Why was Bentham so happy at Ford Abbey? Life there provided Bentham, a solitary man by nature, with sustained periods of time with friends who were dear to him. The Mills-James, his wife Harriet, and growing family - accompanied Bentham on each visit. $^{24}$ The Mills lived near Bentham at 2 Queen's Square, Westminster, in a house rented from Bentham, from 1814 until 1831, and James and his young son John Stuart Mill had stayed with Bentham at Barrow Green. Both James and Harriet Mill helped with the running of Bentham's life, managing some household and business matters. It is difficult to underestimate the closeness of Bentham and Mill at this time. Mill probably met Bentham sometime in 1808. He described himself as 'a most faithful and fervent disciple' of the principle of utility, and indeed Bentham's 'favourite

\footnotetext{
${ }^{20}$ Letter from James Mill, 28 August 1814, The Correspondence and Works of David Ricardo, ed. P. Sraffa, Cambridge, 1952, vi. p. 160.

${ }^{21}$ Letter to his sister, Anne Horner, 8 August 1814, Memoirs and Correspondence of Francis Horner, M.P., ed. L. Horner, 2 vols., London, 1843, ii. pp. 178-80.

${ }^{22}$ Walter Coulson to Thomas Coulson, his father, 6 November 1815, Coulson Family Papers, Cornwall Record Office, Truro, X696/45.

${ }^{23}$ Letter 2299 to an Unknown Correspondent, 13 December 1814, Correspondence (CW), viii. 440.

${ }^{24}$ Bentham himself had little experience of family life. By the age of twelve, when he left to go to Oxford, Bentham had lost his mother, two brothers, and three sisters; his brother Samuel, nine years younger than Bentham was the only sibling to survive.
} 
disciple'. ${ }^{25}$ They discussed whatever each was working on: in his first surviving letter from Ford Abbey Bentham told his brother, Samuel, that 'after dinner Mill and I always walk in a duet, to digest what we have written' ${ }^{26}$ During their long friendship Mill and Bentham quarrelled from time to time, for example over borrowing each others books, and the editorship of the Westminster Review, and they quarrelled at Ford Abbey. Having arrived at the Abbey for the first time in July 1814, by September 1814 Mill had angered Bentham. Bentham disliked confrontation and quarrels, and Mill describes Bentham's anger as expressed 'by deportment so strongly', that Mill considered leaving the Abbey. A letter survives from Mill in which he surmised that the reason for Bentham's umbrage was that he, Mill, had gone out riding with Joseph Hume instead of walking with Bentham. ${ }^{27}$ As a result of this quarrel Mill wrote that he planned to remain at Ford Abbey for the summer to avoid arousing suspicion of a rift between them, but would move out of Queen's Square after Christmas. But the disagreement was settled, although no record survives to explain how, and the Mills and Bentham remained close until the 1820s.

Apart from the Mills, from amongst his closest friends Bentham also invited Sir Samuel Romilly, MP and former Solicitor-General, whom he had known for over twenty years, who came with his wife Anne and daughter Sophie, and Francis Place, a tailor, whom Bentham had known for five years, who came with his daughter Annie. Romilly and Place both visited Ford Abbey in 1817 and their visits coincided. Place, who lived and worked in Charing Cross, was a self-educated man, radical thinker, and social reformer. In 1807 Place had led the campaign to elect Sir Francis Burdett to Parliament for the constituency of Westminster, and continued to groom radical candidates for that constituency for twenty years. Place, like Mill, looked after some of Bentham's affairs, especially financial matters, as well as often dealing with printers and publishers on Bentham's behalf. Bentham met him through James Mill in 1812, and the three men shared many passions, in particular, for social and parliamentary reform. Place described Bentham as '[m]y good old friend and master', who treated him not as a tradesman but as an equal: 'He used to annoy some of his friends by praising his friend Place the tailor'. Place was aware of prejudice against tradesmen such as himself, and believed that Bentham told the Romillys that he (Place)

\footnotetext{
${ }^{25}$ Letter 2291 from James Mill, 19 September 1814, Correspondence (CW), viii. p. 417.

${ }^{26}$ Letter 2283 to Sir Samuel Bentham, 19 July 1814, ibid. p. 404.

${ }^{27}$ Letter 2291 from James Mill, 19 September 1814, ibid. viii. 419.
} 
was at Ford Abbey, in case they objected to his presence there, but they did not. ${ }^{28}$ From her record of their introduction Anne Romilly certainly did not know Place was there: Bentham said to Samuel: 'Romilly come here, let me introduce you to Mr Place, Maker of Small Clothes and Members of Parliament; and to our surprise we saw the famous Tailor of Charing Cross'. Despite their outward ease, the Romillys and Place regarded each other circumspectly. Anne Romilly continues: 'we found [him] a very pleasant sensible man, who had read a great deal, and spoke very well without anything vulgar about him, but the tone of his voice'. ${ }^{29}$ And Place, though pleased to live in close proximity with such 'great folks' for a while, was glad when they left Ford Abbey: 'I am not sorry they are gone, there will be now no more dressing for dinner in a cold room [...] besides I want to have ourselves to ourselves' ${ }^{30}$ However, the Romillys' daughter Sophie befriended Annie, Place's second daughter, at this time a governess, ${ }^{31}$ who had accompanied Place. Sophie also played shuttlecock and battledore with Place in the Great Hall, and thought him a member of Parliament, much to Bentham's amusement. ${ }^{32}$ In fact Place and Romilly continued their acquaintance, and in 1818 Samuel Romilly was elected MP for Westminster. The relationship between Bentham and Place, both capable of irascibility, was close, and endured until Bentham's death. Bentham addressed Place as 'My dear and worthy friend', light-heartedly as 'Son Francis', and just before his visit to Ford Abbey wrote: 'Every body here burns with impatience to take the Taylorus Taylororum by the hand'. ${ }^{33}$ Place later wrote of Bentham: 'I owe a vast debt for what is good and of high value to him'. 34

A final friend should be mentioned here, namely John Herbert Koe, who spent very little time at the Abbey, but played an essential role in maintaining the quality of Bentham's life in Devon. John Herbert Koe, formerly Bentham's amanuensis, was now working as an attorney in London, and lived at this time with his wife, Anne, at

\footnotetext{
28 'Gentlemen cannot associate with tradesmen': The Autobiography of Francis Place (1771-1854), ed. M. Thale, Cambridge, 1972, p. 250. At this same reference see an account of Bentham taking a walk with Place while Place visited his customers.

${ }^{29}$ Romilly-Edgeworth Letters, pp. 175-6.

${ }^{30}$ Francis Place to his wife Elizabeth, 29 September 1817, Place Papers, British Library Add. MS 35,143 fo. 300 .

${ }^{31}$ According to Place, Annie was a governess to the daughter of Samuel Greatheed of Landford Lodge, near Salisbury, Wiltshire. See The Autobiography of Francis Place, p. 6.

${ }^{32}$ Ibid., p. 251.

${ }^{33}$ Letter 2395 to Francis Place, 31 July 1817, Correspondence $(C W)$, ed. S. Conway, Oxford, 1989, ix. p. 28.
} 
Queen Square Place, Bentham's London home. ${ }^{35}$ During Bentham's absence in Devon, Koe acted as Bentham's secretary, sending down to Ford Abbey literary and domestic items forgotten or newly required, in addition to regular supplies of paper, sealing wax, and a steady supply of periodicals which Bentham and Mill read avidly. Koe also bought new books, sent manuscripts to the printers, and circulated Bentham's printed works. Bentham's letters to Koe, which he preserved, provide the most comprehensive record of Bentham's life at this time.

Apart from Bentham's friends, two other types of visitors came to Ford Abbey while Bentham lived there: the interested passers-by, and the local gentry. It was the custom at this time that houses of note such as Ford Abbey could be visited, and a tour of the house undertaken with a member of the household staff. Soon after he first arrived, Bentham wrote to his brother Samuel:

Fourteen visitors to see the place in one company this day, 5 or 7 in another. Scarce a day passes without some company at least: generally two; yesterday there were three. If you have a mind to get rich, come here, put on a livery, and attend them. ${ }^{36}$

In August 1817, Francis Place wrote to his wife about such visits, which carried on around Bentham, Mill, Colls (Bentham's amanuensis), and Place at work in the saloon:

Several parties have been to see the Abbey and have been shewn by the house maid into all the rooms. Colls has a small table nearby opposite to me, by the side of the organ - the three of us have each a quantity of books and one of the small stands you have seen in the Mills study, on our tables, covered with papers, and to strangers we must appear a droll

\footnotetext{
${ }^{34}$ Correspondence (CW), ix. pp. 8, 9. In a letter to Harriet Grote, 1836, quoted in Autobiography of Francis Place, p. 250.

${ }^{35}$ John Herbert Koe (1783-1860), Bentham amanuensis c.1800-10, had married Anne Koe née Jump (1793-1862) on 24 August 1815. Koe became a QC in 1842, and a County Court Judge 1847-60.

Following the Mills' example of naming their children after admired friends, the Koes named their first child, born on 18 June 1816, Bentham Dumont Koe.

${ }^{36}$ Letter 2286 to Samuel Bentham, 11 August 1814, Correspondence $(C W)$, viii. p. 411.
} 
set out. I should like to hear their remarks, some of the parties are genteel, and some very well dressed up vulgarity. ${ }^{37}$

In fact in the previous year Bentham recorded the remarks of another party of visitors who, when told Bentham was the present occupant of the house, exclaimed:

\begin{abstract}
"Ah, what a pity, that we did not know of it that we might have taken a more particular view of him. And so was that he that was sitting in the saloon? how good, to let us see him notwithstanding! Oh yes-that was just what might have been expected of him: that is just his character." ${ }^{\text {,3 }}$
\end{abstract}

Bentham became acquainted with two members of the local gentry. The vicar of Winsham, Mr Festing, visited and dined at Ford Abbey. Bentham also had contact with his near neighbour, John Bragge ${ }^{39}$ of Sadborow House, with whom he tried to trace a possible connection with James Bentham, a merchant in South Carolina, who was born in Dorset. ${ }^{40}$ These two neighbours were accorded an appropriate degree of respect, and when invited to dine at Ford Abbey, did so in the large dining room. ${ }^{41} \mathrm{~A}$ visit from a notable family like the Romillys caused a stir among the local community, and Bentham tried to deal even handedly with both local families. The Festings were invited to dine at Ford Abbey with the Romillys on Saturday 27 September 1817 , and on the following day Bentham sent Romilly, with Mill and Place, to visit the Bragges at Sadborow House, and to worship, in Bentham's words, 'the beautiful and virtuous foe'. ${ }^{42}$ Francis Place, less appreciative of Mrs Bragge's charms called her a 'singular piece of starched up antiquity'. He also related an incident soon afterwards when the 'two painted personages', Mrs and Miss Bragge, ${ }^{43}$ called at Ford Abbey to pay their respects to Sir Samuel and Lady Romilly, and mistaking Place's daughter, Annie, and Mrs Mill (both dressed to visit Mr Festing) for Lady Romilly paid court to both

\footnotetext{
${ }^{37}$ Francis Place to his wife, Elizabeth, 7 August 1817, Place Papers, British Library Add. MS 35,143 fo. 285 .

${ }^{38}$ Letter 2356 to John Herbert Koe, 1 August 1816, Correspondence (CW), viii. p. 539.

${ }^{39}$ John Bragge (1763-1843) had married Anne Ledwell (b.1761) in 1784.

${ }^{40}$ See for example letters from John Bragge to Bentham on the subject: Letters 2361, 29 September 1816;, 2363, 27 October 1816; 2367, 10 November 1816; and 2373, 4 December 1816 in Correspondence $(C W)$, vol. viii. pp. 554-55, 556-57, 563, and 569.

${ }^{41}$ Francis Place to his wife, Elizabeth, 7 August 1817, Place Papers, British Library Add. MS 35,143 fo. 285 .

${ }^{42}$ Letter 2416 to John Herbert Koe, 29 September 1817, Correspondence $(C W)$, ix. p.65.
} 
women, until James Mill came down from his studies in the saloon above to reveal the misunderstanding to, as Place wrote, 'the jocularity of some and the disappointment of the others'. ${ }^{44}$

Although life at Ford Abbey appears happy and relaxed, Place's letters record other aspects of rural Devon life in 1817. While visiting an estate belonging to his friend Edward Wakefield in Yarcombe in North Devon, 'on a one hundred mile round trip from the Abbey', Place noted:

Now for the farmers, their wives and children-such a set of wretches, all beggars-all entirely subdued in mind, if ever there was any mind among them [...] they toil in their uncouth, injudicious way, without ceasing [...] In all the route, in all parts of it, in the villages and lone houses, desolation seems to have stalked through the land, poverty and dirt, and rags, and nothing but poverty dirt and rags among the common people, and the small towns seem going to decay.

Mill and Place, however, were not above taking advantage of the desolation that stalked nearer Ford Abbey themselves:

We went to an old ruin of a house belonging to a fool, where in a garrett was and is about a cart load of books, all more or less injured by the weather, and all in a sad state of decay-we robbed the house of about half a dozen and intend committing a second robbery.

\section{Pursuits: Physical, cultural, and horticultural}

Another reason for Bentham's satisfaction with life at the Abbey may have been that it provided opportunities for him to continue many of the interests in his life. The Abbey allowed him to maintain and enrich a lifelong interest in horticulture and botany, shared by his brother and later by his nephew, George. ${ }^{45}$ Bentham throughout his life wrote to correspondents in North and South America, and in Europe, in a

\footnotetext{
${ }^{43}$ Either Miss Lucy Bragge (1785-1872) or Miss Charlotte Bragge (1791-1856).

${ }^{44}$ Francis Place to his wife Elizabeth, 29 September 1817, Place Papers, British Library Add. MS 35,143 fo. 300 .
} 
quest to collect new seeds and new plants, and he visited botanical gardens and hot houses in the London area. At Ford Abbey he was preoccupied with things horticultural. He described the basis of his agreement with the owner, 'not as a Boarder but as House-keeper on a lease', ${ }^{46}$ and as a housekeeper he plunged into plans to augment the gardens, and alter the grounds in front of the Abbey. Bentham laid out a terrace and cleaned the pond of rubbish. He purchased many new plants and shrubs. In October 1814 he was on the track of a Devon nursery that was to sell off its stock of trees and flowering shrubs at the end of its lease in the following March. ${ }^{47}$ No records remain of what Bentham bought, but he stated in a letter to his landlord, John Fraunceis Gwyn, that during his tenure of Ford Abbey, he had spent 'between three and four hundred pounds on fruit trees, shrubs, and flowers', and that 'every bit of wall that would receive a fruit tree has received one' ${ }^{48}$ Also available at Ford Abbey were greenhouses and hothouses. Bentham reported in August 1817 that the Egyptian cucumber, that he had grown with seeds from Paris in the cucumber frames at Ford Abbey, had fruited and was pronounced 'super excellent'. ${ }^{49}$ (At some point during his stay Bentham had spent six shillings on glass for the cucumber frames). ${ }^{50}$ The fruit Bentham was able to grow there was a source of delight and concern to him. He wrote in August 1816:

Ripening of autumn fruits still, as Peaches and Nectarines depend on future change for the better. Grapes in a great degree abortive. Apricots plenty and ripening. On Table as good a melon as ever was tasted. ${ }^{51}$

And Francis Place confirms in the following year that the supply of fruit was still excellent: '[P]udding, generally, fruit—viz melons, strawberrys, goosberrys, currants, grapes'. 52

The flowers too provided a keen source of interest for Bentham, and at the end of his lease, again in the long letter to Gwyn, squabbling over who owed money to

\footnotetext{
${ }^{45}$ George Bentham became a distinguished botanist and author, President of the Linnean Society.

${ }^{46}$ Letter 2337 to Aaron Burr, 23 February 1816, Correspondence $(C W)$, viii. p. 510.

${ }^{47}$ Letter 2298 to John Herbert Koe, 24 November 1814, ibid., viii. pp. 438-40.

${ }^{48}$ Letter 2497 to John Fraunceis Gwyn, 31 July 1818, ibid., ix. p. 229.

${ }^{49}$ Letter 2403 to John Herbert Koe, 21 August 1817, ibid., ix. p. 46.

${ }^{50}$ Letter 2501 to John Fraunceis Gwyn, 8 August 1818, ibid., ix. p. 243.

${ }^{51}$ Letter 2357 to John Herbert Koe, 7 August 1816, ibid., viii. p. 542.

${ }^{52}$ Francis Place to his wife, Elizabeth, 4 August 1817, Place Papers, British Library, Add Ms 35,143 fo. 285 .
} 
whom, Bentham wrote rather petulantly: 'You must have observed already more than once to how great an extent well trimmed walks, and borders with flowers, have succeeded to couch-grass, nettles, and thistles'. Flowering plants and shrubs were grown indoors and out, with two tiers of potted plants in the parlour, more facing the sun in the Great Hall, and others in the cloisters. The work undertaken by the gardeners during his first stay was reported on arrival for his second visit as answering his expectations completely, except for the

ravages of cursed geese and peacock, who are become florists, and in particular carnation-fanciers. Their wings are clipped they have been banished to the upper pond, where it is hoped so long as flowers continue, they will. ${ }^{53}$

Within a week Bentham had given the geese to Viscountess Bridport, who lived at nearby Cricket St Thomas, and she gave him, presumably in exchange, some peafowls. ${ }^{54}$ At the start of his second visit to Ford Abbey Bentham wrote to Koe to ask him to request Harriet Mill to bring down with her three botanical books from London, as well as striped Phlox, wrapped up in outsize cabbage-leaves for transportation, and the seeds of Siberian flax. ${ }^{55} \mathrm{He}$ also requested from his London garden periwinkles and sumacs, and the seeds of bladder senna, laburnum, and everlasting pea. ${ }^{56}$ Bentham also sent plants from the Abbey to London for Mrs Koe, including campanula, saxefrage, heartsease, cistus, and sweet william. He lists eight plants in November $1817^{57}$ which he had fixed upon with the gardener, who probably related the story to Gwyn, hence Bentham's comment to Gwyn:

I took care [...] to charge [the gardener] in no instance to lessen the Stock of any thing that he found there, nor, without leaving specimens there, to send up any of the plants which I myself had introduced. ${ }^{58}$

\footnotetext{
${ }^{53}$ Letter 2356 to John Herbert Koe, 1 August 1816, Correspondence (CW), viii. 539.

${ }^{54}$ Letter 2357 to John Herbert Koe, 7 August 1816, ibid., viii. p. 542. Maria Sophia Bridport (1746?1831), was the second wife and widow of Alexander Hood (1727-1814), Viscount Bridport, who lived at Cricket St Thomas, Somerset, some two miles from Ford Abbey.

${ }^{55}$ Letter 2358 to John Herbert Koe, 12-17 August 1816, ibid., viii. p. 544.

${ }^{56}$ Letter 2364 to John Herbert Koe, 27 October 1816, ibid., viii. p. 558.

${ }^{57}$ Letter 2432 to John Herbert Koe, 22 November 1817, ibid., ix. p. 122.

${ }^{58}$ Letter 2497 to John Fraunceis Gwyn, 31 July 1818, ibid., xi. p. 229.
} 
Ever on the look out for new plants, while at Ford Abbey Bentham made contact with a community of those interested in horticulture. Mrs Bawdon, the wife of an attorney at Chard whom Bentham met on business in 1817, on first acquaintance gave Bentham some 'curious and valuable seeds', and she later sent him anemone seeds. ${ }^{59}$ Francis Festing, the Vicar of nearby Winsham, gave him a dahlia, which Bentham believed was sold for 4 guineas in Hammersmith, but for three pence in Dorset. Festing also reported that he thought a double dahlia was purchasable. ${ }^{60}$ After he left Ford Abbey, Bentham kept in touch with William Bonfield, the gardener at Leigh House about three quarters of a mile from the Abbey, and they continued to exchange news of plants and seeds. In October 1819 for example they discussed pumpkins and squash, and in 1823 Bentham sent roots of an unidentified plant to Bonfield, who kept some himself and distributed some to Mrs Bawdon and Revd Festing. In March 1823 Bonfield sent to Bentham chrysanthemums, and some seeds from Mrs Bawden. ${ }^{61}$

Wise in the ways of horticulture, Bentham was less successful in dealing with two-acres of land adjacent to the Abbey's garden. He rented it to a neighbouring farmer, who sewed flax, which according to Gwyn's factor would damage the land, and Bentham had to forfeit the rent he received to compensate Gwyn. Having learnt a lesson from the sewing of flax, Bentham then let out to a local butcher a meadow on which to keep his stock, and 'much manure [was] consequently deposited' to enrich the soil. ${ }^{62}$

Another preoccupation for Bentham was icehouses; he had tried to build one in his Westminster garden, and manuscripts survive in Bentham's hand, entitled 'Frigidarium', written between 1794 and 1809. Early in the nineteenth century icehouses were usually found in the houses or grounds of the wealthy. Buried in the garden, or in the cellar, ice was imported into the icehouse in winter, and used for preserving food surpluses from season to season (chilled but probably not frozen), or making iced puddings and drinks. Bentham planned to extend the potential of icehouses. In pursuit of the greatest happiness of the greatest number he sought to

\footnotetext{
${ }^{59}$ Letter 2433 to Francis Place, 24 November 1817 and letter 2960 from William Bonfield, 16 March 1823, ibid., xi. pp. 124, 219.

${ }^{60}$ Revd Francis Joseph Horstead Festing, Vicar of Winsham, Somerset, approximately one and a half miles from Ford Abbey. Letter 2403 to John Herbert Koe, 21 August 1817, ibid., ix. p. 46.

${ }^{61}$ Letter 2566 to Bonfield, 9 October 1819, ix. 357, and Letter 2960 from Bonfield, 16 March 1823, ibid., xi. p. 219.

${ }^{62}$ Letter 2497 to John Fraunceis Gwyn, 31 July 1818, ibid., ix. pp. 229-30.
} 
preserve food in times of plenty for times of scarcity. His papers reveal that he hoped the icehouse would preserve vegetables, fruit, milk products, meats and fish, would hasten ripening fruits, the brewing of beer, the fermentation of wine, the drying of wood for musical instruments, and, as so often ahead of his time, would preserve dead bodies for a yet-to-be-established national bank for anatomical study. ${ }^{63}$ Bentham planned to erect the icehouse in his garden with Peter Mark Roget, ${ }^{64}$ a physician and nephew of Bentham's friend Samuel Romilly, and in November1800 Roget went to stay with Bentham in Westminster for the purpose of building the icehouse. But Bentham's plans exceeded his knowledge, and while at Queen Square Place, Roget wrote to his mother: 'Mr. Bentham will contribute very little because he understands nothing of it'. ${ }^{65}$ Although the icehouse was built, the idea was abandoned, and Roget left in early December. ${ }^{66}$

\footnotetext{
${ }^{63}$ UC cvi. 64.

${ }^{64}$ Peter Mark Roget (1779-1869), physician and compiler of the Thesaurus, 1852.

${ }^{65}$ D. L. Emblem, Peter Mark Roget, The World and the Man, New York, 1970, p. 53.

${ }^{66}$ In 1809 the idea had been revived by Bentham: see bills for thatching and fuelling the icehouse UC cvi. 70-1.
} 


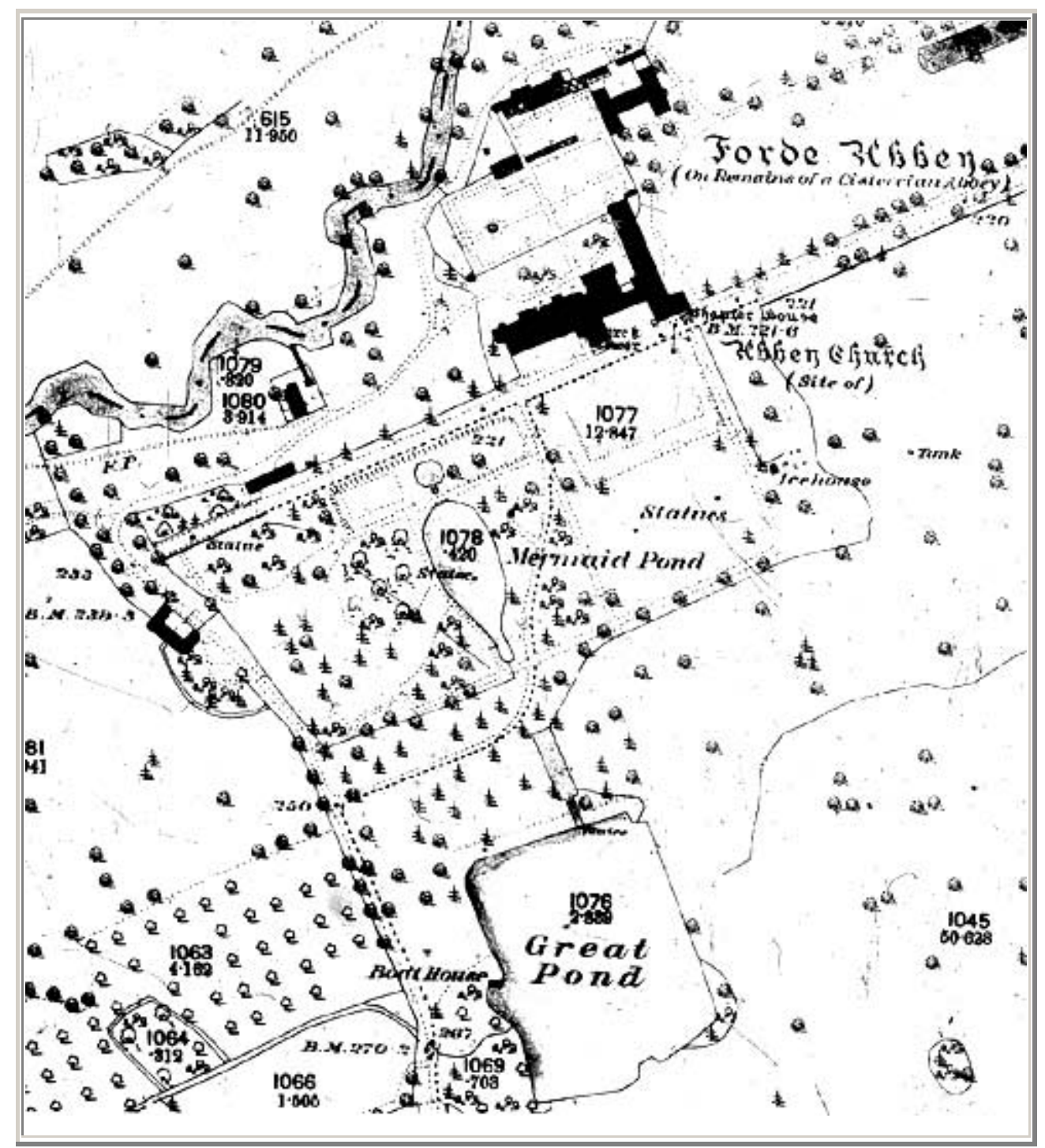

Figure 2. Map of Ford Abbey showing the icehouse in the grounds to the south east of the Abbey

Ford Abbey's icehouse, situated in the grounds to the south east of the Abbey, gave Bentham another opportunity to think about the topic. ${ }^{67}$ But he had little success for the icehouse did not function well. It had obviously worked at some point as he refers to providing Koe's wife with ices on her first visit in October 1815, but by January 1816 the icehouse was not working properly. ${ }^{68}$ A remedy was sought at the start of Bentham's next visit in August 1816, but appears not to have worked, for three months later Bentham was again seeking advice on how to repair it: 'To day I determine with a window washing man who has cured all manner of Ice-houses in the

\footnotetext{
${ }^{67}$ For the site of the icehouse see Ordnance Survey map, 25 inch, Somerset Sheet 92(9), 1889, and Ordnance Survey map, 6 inch, Dorset Sheet 19SW, 1931.

${ }^{68}$ Letter 2335 to John Herbert Koe, 2 January 1816, Correspondence (CW), viii. p. 507.
} 
neighbourhood. He has much experience but talks nonsense'. ${ }^{69}$ Bentham later suggested that his persistence with the problem of the icehouse had been successful, as he wrote to Gwyn in 1818:

The Ice-house, year after year I took a deal of pains about, and some expense: I shall be much disappointed, if, upon your visit to it at this hot Season you do not find it full of ice: a state in which, if I am not misinformed you never yet saw it in the summer time. ${ }^{70}$

But a subsequent note written by Bentham on his copy of this letter, and dated 16 September 1818, states: 'After all, it appears that it will not hold the Ice'. Music too was a keen passion of Bentham's. He had been instructed in the rudiments of writing and reading music before the age of five, and had had music lessons from the age of six. He played the harpsichord, the violin, and the piano. He had purchased a violin in 1764, aged 21, ${ }^{71}$ and according to a visitor to Queen Square Place in 1822, Bentham had three pianos: one in his parlour, one in the library, and one in the dining room. ${ }^{72}$ After making extensive enquiries in 1820 he also had an organ installed at his home. ${ }^{73}$ The organ at Ford Abbey had caused Bentham problems for on 12 August 1816 he wrote: 'the Organ has been taken to pieces and I hope put to rights, by assistance from a sort of Gentleman-Malster 5 miles off an acquaintance of the Gardener's. The fault which is now discovered being clearly out of the Carpenter's power to end. ${ }^{74}$ Bentham played the organ while there, and soon after arriving in July 1816 he wrote to Koe asking him to send down a copy of the concertos of Handel, ${ }^{75}$ a life-long favourite of Bentham's. There were other opportunities for music-making at Ford Abbey, for, as already mentioned, John Stuart Mill had reported that one of the dining rooms

\footnotetext{
${ }^{69}$ Letter 2369 to John Herbert Koe, 18 November 1816, ibid., viii. pp. 566-7.

${ }^{70}$ Letter 2497 to John Fraunceis Gwyn, 31 July 1818, ibid., ix. pp. 229-30.

${ }^{71}$ The Old Radical: Representations of Jeremy Bentham, ed. Catherine Fuller, London, 1998, p. 26.

${ }^{72}$ Rush, A Residence, p. 149.

${ }^{73}$ Letters 2622, 16 May 1820; 2625, 17? May 1820; 2627, 18 May 1820; 2631, 20 May 1820; and 2641, 6 June 1820, Correspondence (CW), ix. pp. 442-43, 444, 446, 449-50, 462-63, and Letter 3017, 11 November 1823, Correspondence (CW), xi. pp. 314-15.

${ }^{74}$ Letter 2358 to John Herbert Koe, 12-17 August 1816, ibid., viii. p. 543.

${ }^{75}$ Letter 2354 to John Herbert Koe, 29 July 1816, ibid., viii. p. 536. Whether there was more than one organ remains somewhat of a puzzle for according to Place, Colls worked at a small table opposite Place in the saloon, by the side of the organ, and years later Bentham too recorded that there was an organ in the saloon, but today the only organ is situated in the chapel.
} 
contained 'various kinds of musical instruments', ${ }^{76}$ and Bentham relates two incidents of music making at Ford Abbey. The first was at Christmas 1816 when local musicians came to play in the great hall on Christmas day, and on new year's day when there was also a dance led by Mrs Stoker, Bentham's housekeeper and James Hume, his amanuensis. ${ }^{77}$ The second took place on Sunday 28 September 1817 when Bentham had arranged for a choir and musicians to come to the Abbey to give a concert for the Romillys. As dinner finished,

to the no small surprize of all of them but me, all on a sudden our ears were saluted with a chorus from the sweet singers of our Israel, with their presiding band. Mixture of surprize and delight in all countenances: since the Christmas exhibition the performers were all considerably improved, and of the pieces whatever they were, anthems or whatever else, there was not one that Mrs M[ill] or myself recollected to have heard before.'

As the musicians played Bentham had taken Sophie Romilly to peep at the concert through folding doors. Lady Romilly followed them, and led all the diners into the room and sat by the fire to listen to the musicians. ${ }^{78}$

Bentham was also able to pursue at Ford Abbey his interest in exercise and fitness. Famous for jogging through St James's Park adjacent to his home in London, Bentham continued to exercise at Ford Abbey, regulating the time, the place, and the company. ${ }^{79}$ According to Francis Place, at one o'clock all three of them (Bentham, Mill, and Place) walked in the lanes and fields together for an hour, and then after dinner Place and Mill took a 'sharp walk' for two hours, and then either Place or Mill walked with Bentham for an hour. ${ }^{80}$ In wet weather walking in the cloisters, the great

\footnotetext{
${ }^{76}$ A. Bain, J.S. Mill: A Criticism, London, 1882, p. 4.

${ }^{77}$ Letter 2335 to John Herbert Koe, 2 January 1816, Correspondence (CW), viii. p. 507.

${ }^{78}$ Letters 2416 and 2417 to John Herbert Koe, 29 September and 30 September 1817, Correspondence $(C W)$, ix. pp. 65, 70 .

${ }^{79}$ Lord Byron called Bentham's jogging 'Jerry Bentham's Cruise', see Parry, The Last Days of Lord Byron, Paris, 1826, pp. 154-59, and more prosaically Mrs Bonfield, the housekeeper at Ford Abbey and the wife of the gardener at Leigh House, described it as 'running up and down the garden walks, with arms akimbo', Notes \& Queries for Somerset and Dorset, vol. xxii, (1938), p. 10.

${ }^{80}$ Francis Place to his wife, Elizabeth, 7 August 1817, Place Papers, British Library Add. MS 35,143 fo. 285 .
} 
hall, and the monks' dormitory was substituted. Little wonder that Place wrote to his wife:

Having worn out my thick shoes, rubbed the toes out of my thin onesmade a hole through my slippers, and having none to wear, save only those sent in the last parcel, I took myself to Chard, a distance of nearly 4 miles over the hills, to order a pair of clod hoppers. ${ }^{81}$

Bentham confirmed this exercise regimen when writing to his Genevan friend and editor, Étienne Dumont:

Between your breakfast and dinner, we all three circumgirate on the outside of the Deer Park with deer in it; this occupies three quarters of an hour; this is the only social trium walk; unless for some special purpose it receive an incidental extension, name of the process, antepostjentacularisation. ${ }^{82}$ Dinner at 6: after dinner circumgyration tête a tête in a delightful spot within the ornamented ground, ycleped the Mount: one afternoon you and I; the next, he and I, and so alternately. ${ }^{83}$

Anne Romilly in her letter to Maria Edgeworth provides a key to some of these words which were used in the Bentham household: to vibrate was to walk up and down, but a circumgyration was a walk around the grounds. ${ }^{84}$

Ford Abbey also gave space and opportunity for other sports: shuttlecock was played in the Great Hall, and fives in the monks' dormitory corridor throughout Bentham's stay there. ${ }^{85}$ Bentham boasted that instead of taking physic he played fives every morning, beating a boy of 18 , James Hume, his amanuensis at the time. ${ }^{86}$ James Hume has not left a record of his experiences at Ford Abbey, but nearly thirty years

\footnotetext{
${ }^{81}$ Francis Place to his wife, Elizabeth, 28 August 1817, Place Papers, British Library Add. MS 35,143 fo. 291.

${ }^{82}$ The full word is a Bentham coinage, but according to the OED jentacular means of or relating to breakfast.

${ }^{83}$ Letter 2391 to Étienne Dumont, 22 July 1817, Correspondence (CW), ix. 22.

${ }^{84}$ Romilly-Edgeworth Letters, p.176.

${ }^{85}$ See for example Bentham's description of shuttlecocks and fives balls at Ford Abbey, Letter 2297 to Unknown Correspondent, 9 November 1814, Correspondence $(C W)$, viii. 437.
} 
later and after working for Bentham for thirteen years, not all of them happy, John Flowerdew Colls, Bentham's amanuensis from 1816 until 1829, recounted the experience rather differently:

he would frequently in the morning before breakfast, play at fives with me. [...] Generally I allowed him to be the winner. But once or twice, I was inconsiderate enough, in the ardour of the contest, to return his balls so quickly, as to be myself the victor. ${ }^{87}$

Colls seems to have been an essential item in the fitness regime of the Abbey, for Francis Place records: 'I get a good warming every morning before breakfast in the great hall playing with Colls at shuttlecock, played as we play it it is hard exercise.' Later descriptions of Colls using the gymnasium Bentham installed in the coach house at Queen Square Place go some way to confirming that early training at Ford Abbey stood him in good stead. ${ }^{88}$ Colls also records that Bentham, aged 69, had challenged Lady Romilly, aged 45, to a race along the gravel walk, and describes with relish Bentham's defeat. ${ }^{89}$ Exercise was promoted by all the adults at Ford Abbey; Place records that Harriet Mill marched with the children around the green in front of the house for half an hour before breakfast, and after dinner until bedtime, and that even little James Bentham Mill, then aged three, was seen 'trundling a hoop nearly as tall as himself round the Great Hall, going as fast as the others \& turning the corners with admirable dexterity'.90

\section{Work on Education and Religion}

Ford Abbey also allowed Bentham to continue to write for most of each day as had always been his habit, and the correspondence which provides information about his domestic life at the Abbey also provides information about what he was working on.

\footnotetext{
${ }^{86}$ Letter 2337 to Aaron Burr, 23 February 1816, ibid., viii. 513. James Hume worked for Bentham from March 1815 until November 1816 when he left to take up a post in the East India Company. Colls arrived at Ford Abbey 15 August 1816.

${ }^{87}$ John Flowerdew Colls, Utilitarianism Unmasked, London, 1844, p.13.

${ }^{88}$ See 'Autobiography of John Stuart Mill', Edinburgh Review (1874), vol. cxxxix, no. cclxxxiii, p. 99.

${ }^{89}$ Colls, Utilitarianism Unmasked, p. 13.

${ }^{90}$ Francis Place to his wife, Elizabeth, 17 August 1817, Place Papers, British Library Add. MS 35,143 fo. 289 and fo. 285 .
} 
He wrote on language and logic, and parliamentary reform, but two topics predominated: education and religion.

During his first stay at Ford Abbey Bentham continued to write on what was eventually published as Chrestomathia, a work concerned with education (and using for a title a word meaning useful learning). Bentham and other radicals were keen to widen the scope and availability of education in the early nineteenth century. This particular work was prompted by the interest of, among others, Francis Place and Edward Wakefield, who in 1813 had first expressed a desire to create a non-sectarian secondary school for middle ranking children, with a curriculum in which the humanities were to be outweighed by science and technology, subjects of much greater use to the pupils. The school was to be run on monitorial lines (whereby the taught students teach the untaught). Andrew Bell and Joseph Lancaster were each credited by their own supporters to be the originators of the monitorial system of schooling, which provided a solution to the problem of how to educate cheaply and efficiently children of primary school age. Expanding on this idea, Place and Wakefield's scheme was targeted at secondary schooling, and they were soon joined in the scheme by James Mill, Joseph Hume, and David Ricardo. ${ }^{91}$ The utility of a system of education that could in theory employ one teacher to teach hundreds of pupils, and could thereby be used widely to educate those for whom secondary education was beyond their means, appealed to Bentham. He also saw the advantages of such a school being based on the panopticon principle, and offered part of his large garden at his London home for such a building: being in Westminster, and close to St James's Park, Bentham's garden provided a prime site for such a school. Earlier in 1814 Bentham had begun work on Chrestomathia, which set out the new curriculum, and the teaching methods to be used in the school, and continued to work on it when he arrived at Ford Abbey. Bentham reported to Koe that in December 1814 for two or three days he had been indexing the latest edition of Bell's Elements of Tuition. ${ }^{92}$ The work Bentham had been doing refers specifically to Table 2 in Chrestomathia, which outlined the relationship between Bell's work, and the principles of the management of the chrestomathic school coupled with the exercises to be performed to obtain

\footnotetext{
${ }^{91}$ Many of those involved in the Chrestomathic School were also involved in the London Mechanics Institution founded in 1824, and the new University of London founded in 1826.

${ }^{92}$ Bell had first outlined his method of education in 1797 in a work entitled An Experiment in Education, made at the Male Asylum of Madras, London, 1797.
} 
intellectual instruction. ${ }^{93}$ A glance at the Table reveals how rigorously and tirelessly Bentham worked on this cross-referencing exercise. Such attention to detail sometimes prevented Bentham from keeping the end in view, and drew criticism from friends and enemies alike. Mill regretted this obsessive thoroughness, and while at Ford Abbey he wrote to their mutual friend Dumont: 'Though the school, in itself is an important object, you will regret I know that so much of his time should have been spent on elementary topics'. ${ }^{94}$ Chrestomathia was printed in parts from 1815 , but it was not until 1817 that the work was finally published. Bentham sent parts of the work and instructions from Ford Abbey to the printers in London, and subsequently sent instructions to Koe in London detailing which parts and to whom they should be sent, and Koe accordingly sent the work to France and America, as well as to friends and possible sponsors in England. But the plan to build a Chrestomathic School failed, in part because of insufficient funds, and in part because Bentham withdrew his earlier offer to allow the school to be built in the garden of his house in London. ${ }^{95}$

The subject of education was current at Ford Abbey in two other ways. The Chrestomathic School Bentham, Mill, and Place planned would have eased the plight of young men who could not afford the education Bentham himself had hadWestminster School, and Queen's College Oxford. However there were other opportunities for young men of 'middle rank', and one way was to seek employment at an early age with men such as Bentham to work as secretaries or amanuenses. Such a position for a young man of few means could provide training, opportunities, introductions, and experience, the lack of which could put them at a severe disadvantage in the working world of London. Since 1795 Bentham had employed amanuenses, five of whom spent some time at Ford Abbey, either in a working capacity, or as visitors. Bentham seems to have taken seriously his role to provide or supplement the education his amanuenses lacked. Most of Bentham's amanuenses were indigent, a few were not, and the experience and training they gained from such a position, Bentham claimed, improved their chances of employment subsequently: employment which Bentham often seems to have arranged. ${ }^{96}$ In a letter to a French

\footnotetext{
${ }^{93}$ Letter 2301 to John Herbert Koe, 20 December 1814, Correspondence $(C W)$, viii. p. 441.

${ }^{94}$ Letter from James Mill to Etienne Dumont, 1 August 1815, Dumont MSS, Bibliothèque Publique et Universitaire, Geneva.

${ }^{95}$ See, for example, Correspondence (CW), viii. pp. 491, 493, 504, 535-6, 548-9, 550-1, and ix. 24-5.

${ }^{96}$ Ironically a surprising number of Bentham's amanuenses subsequently found employment either in the legal profession or the church, two of the institutions which Bentham criticized severely, and sought to reform.
} 
correspondent, Jean Antoine Gauvain Gallois, dated September 1814, Bentham wrote from Ford Abbey in search of a new amanuensis, as his current secretary, Henry Tomkin Coulson, was to take up a fellowship at Queen's College, Cambridge in October 1814, in what Bentham described as 'a sort of Protestant Canonry, amounting to a comfortable provision for life'. Bentham, who wrote frequently in French to correspondents not only in France, but Greece, South America, and Russia, was in search of a French amanuensis. Bentham was happy to take someone aged between 12 and 14, who, whether from, as he described it, 'scantiness of means, or multitude of children,' was in straitened circumstances. The boy should be neither lame nor nearsighted, but should be able to write clearly and quickly, and have an acquaintance with Latin. Bentham also wanted someone to read to him while he dressed and undressed, partly because his eye sight was weak, and also because the infirmities of old age meant he spent a long time at such tasks. The boy would also attend auctions of books in London: 'all my boys have attended occasionally to bid for books, and, if the cargo bought has not been too heavy to bring in hand or under arm, have brought it home for me', in a bag provided for the purpose. ${ }^{97}$ The boy would also sleep in the same room as Bentham, and dine with him. ${ }^{98}$ In the event Bentham employed the nephew of his friend Joseph Hume, James Hume, who was at Ford Abbey in 1815, and again until November of the following year when, according to Bentham, Joseph Hume had obtained for him the promise of work as a surgeon with the East India Company provided he studied both in London and Edinburgh, and passed the relevant examinations in the meantime. ${ }^{99}$

Hume's replacement was John Flowerdew Colls, from Southwark in South London, who arrived at Ford Abbey and met Bentham for the first time, on 15 August 1816, his fourteenth birthday. Colls had spent a few weeks in Bentham's London home, where Koe had been instructed to send him to Mrs Lucy Peacock's juvenile library at 259 Oxford Street, to improve his handwriting. ${ }^{100}$ Colls travelled to Ford

\footnotetext{
${ }^{97}$ Considering that when he died, 3,544 of Bentham's book were given to the University of London, and this was by no means all his books, it is very likely that many of Bentham's books were purchased by amanuensis at auction, and the bag much used.

${ }^{98}$ For Bentham's description of the duties of an amanuensis, and his discussion of past amanuenses see Letter 2293 to Jean Antoine Gauvain Gallois, September 1814, Correspondence (CW), viii. 429-33.

${ }^{99}$ Letter 2368 to John Herbert Koe, 16 November 1816, ibid., viii. p. 565.

${ }^{100}$ Bentham was keen that Colls should see 'the upright and square hands of the Writing Stationers', 'to see how they manage to form such writing, and get some copies to imitate here'. See Letter 2357 to John Herbert Koe, 7 August 1816, ibid., viii. p. 540. Those of us who work on Bentham's manuscripts
} 
Abbey in a coach with Mrs Mill, arriving on a Thursday, and was soon put to work for by the Saturday Bentham was able to report:

by bad schooling [Colls] is much more deficient in general instruction than I expected: but he reads well beyond expectation, which is a great comfort. [...] Writing I have not yet tried him in. He is under Mill's schooling. ${ }^{101}$

Colls remained with Bentham until 1829, when he went to Trinity College, Cambridge, and was subsequently ordained, working in parishes in Middlesex, Essex, and Hertfordshire. ${ }^{102}$

The fifth amanuensis to visit Ford Abbey was Walter Coulson, cousin of Henry Tomkin Coulson mentioned earlier, and brother of Thomas Coulson who had also worked for Bentham in 1809, before Bentham found him an appointment in the Navy Office. Bentham was introduced to the Coulson family through his brother Samuel Bentham, who worked for the Admiralty and later the Navy Board from 1796 until 1812. Thomas Coulson the father was a master painter who for many years worked at the Royal Dockyard at Devonport, and was described by Bentham as 'a man of cleverness and experience', who had 'a head on his shoulders'. ${ }^{103}$ Widowed in 1801 with four young children in his care, Coulson was grateful for Bentham's interest in his family and reported that Bentham had, in terms of great liberality and friendship, guaranteed him from all expense and trouble with regard to young Thomas's board and clothing. ${ }^{104}$ Bentham certainly believed that his association with Walter Coulson, Coulson's middle son, had increased Walter's prospects:

He came to me when he was about 15 or 16 years old. He lived with me as an Amanuensis for about four or five years. He was, by this means,

\footnotetext{
are grateful for Colls round clear hand, which makes the reading of his manuscripts so much easier than Bentham's hand.

${ }^{101}$ Letter 2358 to John Herbert Koe, 12-17 August 1816, ibid., viii. p. 543.

${ }^{102}$ In 1844 Colls published a memoir of his relationship with Bentham in Utilitarianism Unmasked.

${ }^{103}$ Bowring, x. p. 573.

104 Thomas Senior to Thomas Junior, 16 January 1809, Coulson Family Papers, X696, Cornwall Record Office Truro, X696/1.
} 
qualified to become a Reporter for the Morning Chronicle, which situation I procured for him. ${ }^{105}$

Coulson became the editor of the Globe and Traveller newspaper in 1822, and was later called to the bar, becoming a QC in 1851. Coulson was also godfather to the first child of William Hazlitt, who was a tenant of Bentham's at a house in York Street, Westminster.

At a personal level, Bentham not surprisingly took an interest in the education of John Stuart Mill, the eldest son of James Mill. In July 1812 Bentham wrote to James Mill asking if he, Bentham, could be made John Stuart's guardian in the event of his father's death. Bentham wrote that he could teach him 'how to make Codes and Encyclopaedias, and whatsoever else may be proper to be made, so long as I remain in this vale of tears'. James Mill agreed: 'If I were to die before this poor boy is a man, one of the things that would pinch me most sorely, would be, the being obliged to leave his mind unmade to the degree of excellence, of which I hope to make it.' Mill also wished to leave John as 'a successor worthy of both of us'. ${ }^{106}$ At Ford Abbey, Bentham and his visitors had an opportunity to observe Mill's teaching methods at first hand. Mill's system of education was rigorous, and potentially harmful. While at the Abbey in 1817 Place recorded in letters to his wife his impressions of James Mill's education of his children along monitorial lines. John (then aged 11) taught his sisters Wilhelmina (aged 9) and Clara (aged 7), what had been taught to him by his father. James Mill then checked what ever they had learned from John, and taught John himself. Additionally in 1817 from 5am to 6am John also helped his father check the proofs of The History of British India; John reading the copy and his father checking the proofs. ${ }^{107}$ Place makes many comments, favourable and unfavourable, on the Mill family at their lessons:

I cannot but admire the children here, who give no one any trouble, they have a hard time of it learning their lessons from 6 every morning to 9 and saying them and learning others from 11 to 1 , and learning again in

\footnotetext{
${ }^{105}$ Letter 2689 to José Joaquín de Mora, 19 September 1820, The Correspondence of Jeremy Bentham $(C W)$, ed. S. Conway, Oxford, 1994, x. p. 80.

${ }^{106}$ Letter 2179 to James Mill, 25 July 1812, and Letter 2180 from James Mill, 28 July 1812 , ibid., viii. pp. 253-55.

James Mill, The History of British India, 3 vols., London, 1817.
} 
the afternoon, learning too with a precision utterly unknown by others [...] even little Jim (aged 3) spells words of 4 syllables well.

Although Place admired James Mill's devotion to his children's education, he was shocked by Mill's severity:

Lessons have not been well said this morning by Willie and Clarathere they are now, 3 o clock, plodding over their books, their dinner which they know went up at one, brought down again, and Jon who dines with them, at his books also, for having permitted them to pass when they could not say, and no dinner will any of them get till 6 o clock. This has happened once before since I came-the fault to day isa mistake in one word. Now I could not be so severe'.

But Place adds: 'the learning and reasoning these children have acquired is not equalled by any children in the world' ${ }^{108}$ As a commentator on the teaching provided at Ford Abbey, Francis Place was well qualified. He was not only an observer of James Mill's method of education, but he was also Mill's pupil, being taught Latin by him every morning: 'I have been pacing the walks from 10 to 2, four hours hard work at Latin [...] all lessons and readings are performed aloud [...] If I am not at school no one ever was. ${ }^{109}$

The possible consequences of adopting utilitarian ideas are famously satirized by Charles Dickens in Hard Times published in 1854, and some critics have identified James Mill as the prototype for Thomas Gradgrind, a retired hardware merchant, who advised the school master, Mr M'Choakumchild: 'Teach these boys and girls nothing but Facts. Facts alone are wanted in life'. So severe is the education system followed by Gradgrind with his own children that Raymond Williams commented: 'The education he [Gradgrind] imposes on Tom and Louisa is very unlike the famous education of John Stuart Mill'. ${ }^{110}$ Yet in the opening

\footnotetext{
${ }^{108}$ Francis Place to Elizabeth, his wife, 17 August 1817, Place Papers, British Library Add. MS 35,143 fo. 289.

${ }^{109}$ Francis Place to Elizabeth, his wife, 17 August 1817, Place Papers, British Library Add. MS 35,143 fo. 289.

${ }^{110}$ Raymond Williams, 'Dickens and Social Ideas', in Dickens 1970, ed. M. Slater, New York, 1970, p. 89.
} 
chapter of the novel, Gradgrind visits the local school and questions the schoolboy, Bitzer:

"Bitzer", said Thomas Gradgrind. "Your definition of a horse".

"Quadruped. Graminivorous. Forty teeth, namely twenty-four grinders, four eye-teeth, and twelve incisive. Sheds coat in the spring; in marshy countries, sheds hoofs, too. Hoofs hard, but requiring to be shod with iron. Age known by marks in mouth”. Thus (and much more) Bitzer. ${ }^{111}$

Written thirty seven years earlier by Place to his wife is, by coincidence, the following: "Clara reads as she herself says Natural History. At present she "is reading of Quadrupeds", and really knows what she reads in a surprising manner, and explains the meaning of terms used with care and correctness.' Place does not record the meaning of terms explained by Clara, but it seems probable that her definitions would have met with Thomas Gradgrind's approval.

Place also noted his concern for the mental health of John Stuart Mill:

John is truly a prodigy, a most wonderful fellow, and when his Logic, his Languages, His Mathematics, his Philosophy, shall be combined with a general knowledge of Mankind and the affairs of the world he will be a truly astonishing man-but he will probably be morose and selfish-Mill sees this, and I am operating upon him when the little time I can spare can be applied, to counteract the propensities, so far as to give him a bias, towards the management of his temper, and to produce an extensive consideration of the reasonings and the habits of others when the time shall come for him to observe and practice these things. ${ }^{112}$

Although the glimpse of Mill's education of his children at the Abbey afforded by Place is in some ways alarming, in his own accounts of his time at Ford Abbey John

\footnotetext{
${ }^{111}$ Obviously not a fan of Utilitarianism, Dickens also parodied Bentham in The Mystery of Edwin Drood, London, 1870, Ch. 16: [The] Philanthropist had expressly declared: 'I owe it to my fellowcreatures that he should be, in the words of BENTHAM, where he is the cause of the greatest danger to the smallest number'.

${ }^{112}$ Francis Place to Elizabeth, his wife, 17 August 1817, Place Papers, British Library Add. MS 35,143 fo. 289 .
} 
describes activities more suited to young children such as carriage rides 'Willie and I have had rides in Mr Hume's curricle', and clearing the fish pond:

there has been a groping in the pond for eels. Mr Bragge's two sons went into the mud (after almost all the water had been let out) and groped with their hands for eels. Those caught were, many of them, very large ones. ${ }^{113}$

John also found less obvious compensatory support from the Abbey. He wrote in the first drafts of his Autobiography approximately forty years later that the Abbey itself had played a role in his education:

This sojourn [at Ford Abbey] was, I think, an important circumstance in my education. Nothing contributes more to nourish elevation of sentiments in a people, than the large and free character of their habitations. The middle-age architecture, the baronial hall, and the spacious and lofty rooms, of this fine old place [...] gave the sentiment of a larger and freer existence, and were to me a sort of poetic cultivation, aided also by the character of the grounds in which the Abbey stood; which were riant and secluded, umbrageous, and full of the sound of falling waters. ${ }^{114}$

But Place's concern, echoed by Lady Romilly in her letter to Maria Edgeworth, about the effect of Mill's education upon his eldest son proved well founded and in the winter of 1826-7 John became severely depressed. ${ }^{115}$ The analytic habits instilled in him to associate all mental and moral feelings with good or bad effects, had weakened his ability to feel any emotion: 'My education, I thought, had failed to create these feelings in sufficient strength to resist the dissolving influence of

\footnotetext{
${ }^{113}$ The Earlier Letters of John Stuart Mill (CWJSM), pp. 5, 6.

${ }^{114}$ John Stuart Mill, Autobiography and Literary Essays, ed. J.M. Robson and J. Stillinger, (The Collected Edition of the works of John Stuart Mill), vol. XX, Toronto, 1981, p. 57.

115 'Really if he were my child I should be very uneasy about him'. See Romilly-Edgeworth Letters, pp. 177-8.
} 
analysis'. ${ }^{116}$ In deep despair John turned to Wordsworth, whose poems had a restorative effect on him:

What made Wordsworth's poems a medicine for my state of mind, was that they expressed, not mere outward beauty, but states of feeling, and of thought coloured by feeling, under the excitement of beauty. ${ }^{117}$

Although John attributes his recovery to Wordsworth and the Romantic sensibility, it may have been the 'poetic cultivation' first nurtured at Ford Abbey which gave John the key to such an understanding.

Another topic of work which Bentham carried out while at Ford Abbey concerned religion. The irony of Bentham, a strong critic of the established Church, residing in an Abbey was not lost on either Bentham or his friends. On declining an invitation to Ford Abbey on the grounds of his work as a Master in Chancery, Joseph Jekyll wrote to Bentham on 4 August 1815:

Good Father Abbot, give me your benison; and if a Master in Chancery should be desirous at any time of taking sanctuary in the west, I rest well assured Ford Abbey would grant it. ${ }^{118}$

Bentham wrote as follows to Dumont, who was invited to the Abbey to continue his writings on codification of laws for Geneva:

With the help of the Loretto Angels, it has pleased the Almighty in his omnipotence to create for this special purpose a holy, most holy place called Ford Abbey. Thither repair then my child, upon the wings of young ambition: there shall we reign together, a sub-Trinity in Unity: Holy Ghost for the time being J[ames]. M[ill]. ${ }^{119}$

\footnotetext{
${ }^{116}$ Mill, Autobiography and Literary Essays, p.143.

${ }^{117}$ Ibid., p. 151 .

${ }^{118}$ Letter 2324 from Joseph Jekyll, Correspondence (CW), viii. pp. 492-3.

${ }^{119}$ Letter 2391 to Dumont, 22 July 1817, ibid., ix. p. 20. Dumont was the only one of Bentham's closest friends and collaborator who did not visit Ford Abbey, despite Bentham's enthusiastic invitation.
} 
And Bentham, on awaking to find Francis Place and his daughter Annie had left the Abbey, wrote:

I marched down boldly to the drawing-room making sure of finding you, in that holy place where you had been entombed, when lo! instead of him whom I was seeking I saw nobody but an angel in White cloathing in the form of Mrs Mill, who said unto me "He is risen indeed!", 120

According to Mill, writing to Dumont in August 1815, as Bentham approached a conclusion to the Chrestomathic scheme, he was 'hot upon the subject of religion'. ${ }^{21}$ In fact Chrestomathia, with its ten appendices, occupied Bentham intermittently until 1817, but Mill was correct in saying that Bentham was turning his mind to religion. During his stay at Ford Abbey Bentham was working on Church of Englandism and its Catechism Examined, which was printed in 1817, and published in 1818. Probably in part leading out of his work on education, which proposed to provide a nonsectarian secondary school, this new work was in some ways a response to the schools set up by the Church of England under the auspices of the National Society for the Education of the Poor in the Principles of the Established Church. ${ }^{122}$ Indeed some commentators claim that Bentham may first have considered Church of Englandism as an appendix to Chrestomathia. ${ }^{123}$ The work is critical of the Church of England, and in the words of Romilly: 'undertakes to prove, that Church of Englandism is wholly different from true Christianity, as it is to be learned from the gospel'. ${ }^{124}$ However, the first indication that Bentham was preparing Church of Englandism came, in a letter to Koe of 2 January 1816, six months after Mill's letter to Dumont. ${ }^{125}$ Bentham's planned departure from Ford Abbey had been postponed because he had omitted to tell his housekeeper that he was about to leave, and she had taken in provisions for two weeks. Bentham's eye for economy left him at Ford Abbey for a

\footnotetext{
${ }^{120}$ Letter 2421 to Francis Place, 4 October 1817, ibid., ix. p. 89.

${ }^{121}$ Letter from Mill to Dumont, 1 August 1815, Dumont MSS, Bibliothèque Publique et Universitaire, Geneva.

${ }^{122}$ Ironically of the two proponents of the monitorial method, the non-sectarian British and Foreign School Society, claimed for its founder, Joseph Lancaster, and the sectarian National Society for the Education of the Poor claimed for its founder, Alexander Bell, whose system of education Bentham preferred, and closely followed in Chrestomathia.

${ }^{123}$ Chrestomathia $(C W)$, ed. M.J. Smith and W.H. Burston, Oxford, 1983, Editorial Introduction, p. xiii.

${ }^{124}$ Memoirs of the Life of Sir Samuel Romilly, written by himself; with a selection of his Correspondence, 3 vols., London, 1840, iii. 336.
} 
further fortnight, and he was keen to continue to work, asking Koe for the latest edition of the Missionary Register from which to glean information or perhaps ammunition. By the time Bentham returned to Ford Abbey in the following July a substantial amount of work had been done, but the work was in a portfolio which was left in the coach, which travelled on to Exeter. Bentham believed that a year's work would be lost, so on 1 August 1816 Mill was despatched to Ilminster to retrieve the portfolio, a mission which he successfully accomplised. Bentham breathed a sigh of relief: 'Think of wicked Ms of all sorts [...] them dispersed in various hands some of them Parsonical ones'. ${ }^{126}$ For the remainder of Bentham's stay at Ford Abbey, he requested from Koe upwards of ten periodicals, pamphlets, and/or statutes, from which he extracted information to support his thesis that the clergy were corrupt, money grabbing, and in no way inspired by the example of Christ as set out in the New Testament. ${ }^{127}$ By 1 January 1817, just before leaving Ford Abbey, Bentham declared the work almost ready for the press, ${ }^{128}$ but it was not until his subsequent visit in August 1817 that the final pages were sent to the printers. ${ }^{129}$ However the proofs were received in time for Bentham to give a copy to Samuel Romilly, in his role as friend and former Solicitor-General when he visited Ford Abbey in September 1817, and to ask him to read over the work, and to 'mark the dangerous passages' that might leave Bentham open to accusations of libel. Romilly declined, as he felt the task impossible as the passages likely to give offence were 'too numerous', and advised that the work should never be published. In the following April, Romilly noted in his diary his shock on learning that the work had been published with Bentham's name upon it. ${ }^{130}$ Romilly sent for him, and made him promise to suspend publication, but Bentham did not withdraw the work, and he was not prosecuted.

However, when Mill wrote that Bentham was 'hot on the subject of religion', he was in fact referring to a second work on religion, which Bentham planned to

\footnotetext{
${ }^{125}$ Letter to John Herbert Koe, 2 January 1816, Correspondence (CW), viii. p. 507.

${ }^{126}$ Letters 2353 to John Herbert Koe, 26-8 July 1816 and Letter 2356 to John Herbert Koe, 1 August 1816 , ibid., viii. pp. 534, 538.

${ }^{127}$ Ibid., viii, pp. 543-4, 551, 557, 558, 559, 560-1, 567, 570-1; ix. 4-5.

${ }^{128}$ Letter 2375 to John Herbert Koe, 1 January 1817, ibid., ix. p. 3.

${ }^{129}$ Letter 2405 to John Herbert Koe, 25-7 August 1817, ibid., ix. p. 51.

130 'The subject [...] is treated with so much levity and irreverence that it cannot fail to shock all persons who have any sense of religion. I had prevailed on Bentham till now not to publish it. He desired me to strike out the passages I thought most likely to give offence; but they were so numerous that I was obliged to decline the task; and I understood that he had given up all thoughts of publishing the work. To my astonishment, however, I learned yesterday that it had been advertised the day before with this name, and had been publicly sold': Memoirs of the Life of Sir Samuel Romilly, iii. pp. 336-7.
} 
entitle 'The Usefulness of Religion in the Present Life Examined'. This was a work which Bentham had been considering since 1807, and had worked on quite extensively in 1811. As the title suggests Bentham intended to examine the influence of religion in the light of his principle of utility — did religion contribute to the greatest happiness of the greatest number of people? The first surviving manuscript of this work was dated 10 July 1807, and from Bentham's habit of dating his manuscripts we can see that he reworked this folio at Ford Abbey on 15 July 1815 soon after his arrival for his second visit. Whether the experience of living at Ford Abbey had prompted Bentham to reconsider his ideas is a matter for speculation, but taking as his starting point the manuscript from 1807 he took up the matter again:

While meditating on the subject of religion, and in particular on the influence which the notions presented by that term have or have been supposed to have on the welfare of mankind during the present life, it has frequently occurred to me, that after so much has been said on both sides of the question respecting truth [...] yet the question concerning their utility with reference to the present life [...] together with a life to come has never yet been placed in a full or satisfactory point of view. ${ }^{131}$

Bentham continued to work on the topic during the months after his arrival: for instance on 17 July 1815 he wrote at least twenty-five folios, and on 5 August 1815 twenty-eight. We can also see that he appears to have intended publication of at least part of the work for his refers to 'the occasion of the present publication'. ${ }^{132}$ But, after this burst of enthusiasm, evidence from the manuscripts suggests that Bentham left the subject until 1819-21 when he returned to the work briefly. A small portion of the text was published pseudonymously in $1822,{ }^{133}$ but the full text of 1,575 folios remains in the British Library waiting to be published.

Among those first papers written on religion at Ford Abbey in July 1815 is a plea for freedom of expression, and an apparent acknowledgement that the topic of

\footnotetext{
${ }^{131}$ BL Add. MS 29,809, fo.313.

${ }^{132}$ BL Add. MS 29,809, fo.375, dated 15 July 1815.

${ }^{133}$ Philip Beauchamp, Analysis of the Influence of Natural Religion on the Temporal Happiness of Mankind, London, 1822. The editor of the work was George Grote. The sensitivity of such works
} 
religion and the existence of God was discussed by Bentham and his friends. 'Time may come-and perhaps is not widely distant when the question whether the soul of man be a distinct being or no other than an affection of the body which it is said to animate-and even the question whether God be a distinct being or no other than an affection of that world of which he is considered as the creator and preserver may be discussed with equal good humour and mutual forbearance: and of this state of mind so favourable to charity in the best sense of the word as well as to useful knowledge the author of this paper has long been fortunate enough to behold exemplified a variety of examples. ${ }^{134}$ Perhaps under the continued influence of his surroundings, as well as the company of James Mill and Francis Place, both of whom were professed atheists, Bentham continued to think about religion, and worked on the third of his religious works, Not Paul, but Jesus, while Place was at Ford Abbey in 1817.

It is not clear when Bentham first began work on Not Paul, but Jesus, but one of the earliest manuscripts found so far is dated 27 July 1816, at the start of Bentham's third sojourn at the Abbey. ${ }^{135}$ Certainly a large proportion of the manuscripts are dated between August 1817 and February 1818, coinciding with his fourth stay at the Abbey. According to Francis Place, in a note attached to his copy of the published work, 'The matter of this book was put together by me at $\mathrm{Mr}$ Bentham's request in the months of August and September 1817-during my residence with him at Ford Abbey, Devonshire. ${ }^{136}$ Place's role in the work is disputed: Place himself in his autobiography, which he began in August 1823 (when in fact the work was being printed), ${ }^{137}$ and completed it in 1833, refers only once to the work, specifically to comments on the writers of biography, and attributes the work to Bentham without further comment; ${ }^{138}$ and Place makes no mention of the work in his letters to his wife from Ford Abbey at the time. Most commentators have taken Place's remark to mean that he was the editor, but he does not specifically state this: 'the matter' and 'put together' may mean exactly

\footnotetext{
meant that they were often published pseudonymously to escape prosecution, and Bentham was keen to avoid any publicity which he felt might devalue this other works.

${ }^{134}$ BL Add. MS 29,809, fo. 376.

135 UC clxi. 339.

136 i.e. the copy of Not Paul, but Jesus, at University College London Library, Ogden 577.

${ }^{137}$ See the entry in Bentham's Memorandum Book for 25 January 1823, where Bentham has a note to ask Place about the progress of the work (UC clxxiii. 92).

${ }^{138}$ Autobiography of Francis Place, p.8.
} 
what it says - that manuscripts on the subject were collected and arranged while Place was at Ford Abbey in consultation with Bentham, and this seems the most plausible description of Place's contribution to the work. A few manuscripts have been traced so far with alterations in Place's hand, but the majority of manuscripts appear remarkably clear of any hand except Bentham's. And even if Place was to be considered as the arranger and organiser of the text, most series of manuscripts are wrapped and labelled in Bentham's hand. Finally the fact remains that Bentham had begun work on the project before Place's visit, and continued to work on it from time to time until 1823. The question of the editorship of this work is later complicated by entries in the journal of Colls in 1821 which record sending the manuscripts, apparently for translation, to John Bowring, Bentham's friend and literary executor. ${ }^{139}$ Another possible editor is thrown into the equation in two accounts by John Neal, ${ }^{140}$ an American who stayed with Bentham in 1826, which state that in fact Richard Doane, Bentham's amanuensis from 1819-31, put the work together. ${ }^{141}$ Neal probably gleaned this information from his friendship with John Stuart Mill, whom he had met in 1825. John Stuart Mill, by then aged eighteen, had inaugurated the Utilitarian Society in the winter of 1822/3, which met fortnightly at Bentham's house, to read essays and discuss matters of politics and ethics. Doane and Neal were both members. ${ }^{142}$ That Doane may have been involved in the work is possible: one of the brightest of Bentham's amanuenses, Doane began studying for the Bar in 1824, and later practised as a judge on the Northern Circuit. He remained close to Bentham, doing some work for him until 1831, and after Bentham's death edited the formidable 'Constitutional Code' for the Bowring edition of Bentham's works.

\footnotetext{
${ }^{139}$ See Colls Journal, 18 January 1821, British Library, Add. MS 33,563, fo. 64. John Bowring (17921872), merchant, later radical MP, diplomat, and Bentham's literary executor, had come into contact with Bentham in August 1820, and their friendship was the cause of the rift with the Mill family. As Bowring himself was a Unitarian, and as Bowring later decided not to include any of Bentham's writings on religion in the Collected Works which he produced after Bentham's death, it is unlikely that Bowring would have had a hand himself in arranging the text.

${ }^{140}$ John Neal (1793-1876), first met Bentham in 1825, and staying with him in 1826 whilst making a translation of Dumont's recension of Bentham's work Traités de législation pénale et civile into English. For Neal's identification of Doane, see Neal, Principles of Legislation, Boston, 1830, pp. 15, 34, and Wandering Recollections of a somewhat busy life, Boston,, 1869, p. 55.

${ }^{141}$ Richard Doane (1805-48).

${ }^{142}$ For the meetings of the Utilitarian Society see Mill, Autobiography and Literary Essays, ed. J.M. Robson and J. Stillinger, Toronto, 1981 (CWJSM), pp. 81-3, and Neal, Wandering Recollections, pp. $54-8$
} 
No matter who the final arranger of the work, it is entirely possible, and probably certain, that Bentham talked to Place and Mill about the work on their daily walks, and indeed perhaps even while they worked in the saloon. Place drew a plan of the saloon, setting out the position of the desks at which the three men worked each day, ${ }^{143}$ (an arrangement which is, I think, also a tribute to the closeness of the three friends at this time).

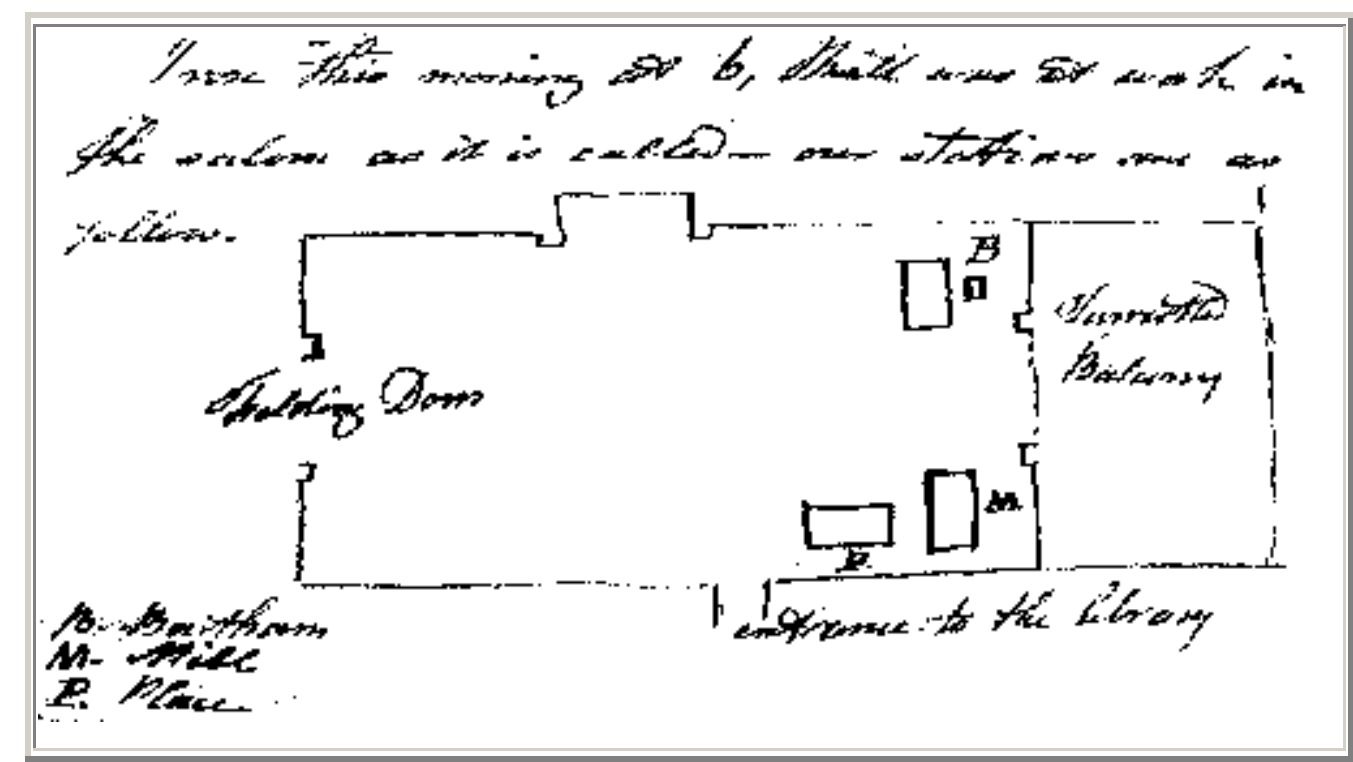

Figure 3. Plan of the first floor room at Ford Abbey where Bentham, Mill and Place worked.

Their collaboration, like their friendship, continuted when they returned to London. Bentham accumulated many books at Ford Abbey to help him with his work: in July 1817 he asked Place to bring a biblical concordance with him, ${ }^{144}$ although he soon afterwards found his own copy at Ford Abbey. ${ }^{145}$ In September and October 1817, after Place had returned to London, he requested two works from Koe which Mill and Place had recommended to him. ${ }^{146}$ Bentham also requested a work by the theologian and moralist William Paley: Horae Paulinae; or the Truth of the Scripture History of St Paul Evinced by a Comparison of the Epistles which bear his name with the Acts of the Apostles and with one another, first published in London in 1790, and

\footnotetext{
${ }^{143}$ For a visual representation of the working practices in the saloon of Place, Mill, and Bentham see the drawing Place included in a letter to his wife see Place Papers, British Library Add. MS 35,143 fo. $281 \mathrm{v}$.

${ }^{144}$ Letter 2395, 31 July 1817 to Francis Place, Correspondence (CW), ix. p. 28.

145 Letter 2397, 9 August 1817, to John Herbert Koe, ibid., ix. p. 31.

${ }^{146}$ Lardner's version of Cardale's The True Doctrine of the New Testament, published in 1767, and A Critical History of the Text of the New Testament published in London 1689-92: see Letter 2422 to John Herbert Koe, 10 October 1817, Correspondence (CW), ix. p. 90.
} 
which by 1816 had reached its eighth edition. ${ }^{147}$ In some ways Bentham's work can be read as a polemic against Paley's work on the life and miracles of St Paul, and Bentham's repeated prompting to Koe to find or purchase the work bears out the importance of the work to Bentham's writing. ${ }^{148}$ But overburdened with material, and hampered by strained eyesight, Bentham asked Koe to read certain texts, and send transcriptions of relevant passages from other books. ${ }^{149}$ By 11 November 1817 Bentham considered the work to be in a state of 'considerable forwardness', and needing only to be divided into chapters and sections to enable a clear Table of Contents to be composed. ${ }^{150}$ In fact he worked on it intermittently until 1823 when it was published. ${ }^{151}$ The work itself was published pseudonymously and therefore reveals no clues as to editorship or authorship. ${ }^{152}$ Only when further work has been done on the printed text and the surviving manuscripts will the role of Place and Mill in this work be fully revealed.

One further connection between Bentham's religious work and Ford Abbey needs to be considered. In Not Paul, but Jesus Bentham purports to criticize the asceticism of the church, which he felt was encouraged by Paul but not by Jesus: an asceticism which was of course opposed Bentham's principle of utility by increasing pain and decreasing pleasure in this life. It is tempting to think Bentham meditated on the subject of Paul's influence on the Christian religion while sitting in the Saloon at Ford Abbey surrounded by the tapestries-Ford Abbey's most precious works of art—made from Raphael's cartoons. Part of a set of ten tapestries commissioned from

\footnotetext{
${ }^{147}$ Letter 2413 to John Herbert Koe, 10 September 1817, Letter 2414 to John Herbert Koe, 19 September 1817, and Letter 2426, from John Herbert Koe, 5 November 1817, Correspondence $(C W)$, ix. pp. 62, 63, 113.

${ }^{148}$ The works of William Paley (1743-1805), Archdeacon of Carlisle from 1782, had provided other stimulus to Bentham. The publication of Paley's Principles of Moral and Political Thought in 1785 in part prompted Bentham to published Introduction to the Principles of Morals and Legislation in 1789, and Paley's Natural Theology of 1802, may have influenced Bentham's work begun in 1807, which contained a critique of Natural Religion, part of which was edited by George Grote as An Analysis of the Influence of Natural Religion on the Temporal Happiness of Mankind in 1824.

${ }^{149}$ Letter 2422 to John Herbert Koe, 10 October 1817, Letter 2432, to John Herbert Koe, 22 November 1817, and Letter 2434, 29 November 1817, Correspondence (CW), ix. pp. 90, 123, 125.

${ }^{150}$ Letter 2427 to John Herbert Koe, 11 November 1817, ibid., ix. p. 117.

${ }^{151}$ The work appeared first in 1821 as Summary View of a Work, intituled Not Paul, but Jesus: As exhibited in Introduction, Plan of the Work, and Titles of Chapters and Section. Not Paul, but Jesus was not published until 1823, and a copy was sent to James Mill in August 1823, on which Mill commented: 'I have carefully perused these pages, \& have been delighted'. See Letter 2987 from James Mill, August 1823, Correspondence $(C W)$, xi. p. 273. Place received his copy on 29 September 1823.

${ }^{152}$ The sensitivity of such works meant that they were often published in this way to escape prosecution, and Bentham was keen to avoid any publicity which he felt might devalue his other works in the process.
} 
Raphael by Pope Leo X in $c .1515$, to complete the decoration of the Sistine Chapel, the tapestries concern the lives of St Peter and St Paul, but only one of the tapestries made at the English tapestry works at Mortlake specifically for Ford Abbey concerned the life of St Paul: the Sacrifice at Lystra before St Paul and St Barnabus. We know Bentham had looked closely at this tapestry for in October 1817 he wrote to Koe that a spirit had suggested to him that his own head 'executed in Worsted' should be placed in this tapestry, but his comments on St Paul in this instance were entirely humorous. ${ }^{153}$ Bentham does examine the miracle of the cure of the cripple at Lystra by St Paul in Not Paul, but Jesus, but no reference is made to the tapestry. This is perhaps because Bentham was examining the veracity of the miracles of St Paul, and Raphael working at the very heart of the Catholic Church, did not question the miracle, but had depicted Paul's anger when, as a result of the miracle, the citizens of Lystra prepared to sacrifice to Paul and Barnabus, thinking them to be gods.

Looking at the work Bentham produced at Ford Abbey allows us to consider what influence this close coterie of friends had upon each other. For example, we have seen that although Bentham was keen for the Romillys to visit and to read his work, he took no notice of Romilly's advice to refrain from publishing Church of Englandism. It has also been noted that Place had a hand in the preparation of Not Paul, but Jesus, and that both Mill and Place recommended books that Bentham should read in association with the work. Although Mill and Place concurred with Bentham's view of religion, neither followed his later example to deny the possibility of corporeal resurrection and give their bodies to anatomy schools. ${ }^{154}$ Place and Mill's ideas about education prompted Bentham to produce Chrestomathia, and the interest in education led to later involvement by all three in the London Mechanics' Institution and London University. The closeness of Mill to Bentham's work, and to his ideas can be see in Bentham's own account their discussions while walking at Ford Abbey. Mill's letters to Dumont from Ford Abbey show Mill's close attention to the work Bentham was doing. Bentham acknowledged that he was being 'vehemently urged

\footnotetext{
${ }^{153}$ Letter 2423, 29 October 1817, to John Herbert Koe, ibid., ix. p. 95.

${ }^{154}$ Many of Bentham's friends shared his views. For example, Jean Baptiste Say wrote: ‘Agréez tous mes remerciemens de l'ouvrage de Mr. Gamaliel Smith, not Paul, but Jesus. Beaucoup de gens seront d'avis qu'on aurait pu substituter la conjonction nor à but.' Letter 2993, 20 August 1823, ibid., ix. p. 283. Thomas Wright Hill wrote: 'I have been much amused, interested and I will add instructed by a work entitled "Not Paul but Jesus" written by an able fellow of whom it is whispered you know something more than the generality of readers': see Letter 3056, 8 March 1823, ibid., xi. p. 360.
} 
on' by Mill to complete Plan of Parliamentary Reform at Ford Abbey, ${ }^{155}$ a work Bentham had started in 1809. The manuscript was sent to the printers from Ford Abbey in January $1817 .{ }^{156}$ The work advocated universal male suffrage, equal electoral districts, payment of MPs, and the secret ballot, but when these reforms were presented to the House of Commons in 1818 by one of Place's radical Westminster MPs, Francis Burdett, not a single Member of Parliament voted for them. It is also interesting to speculate on the role the Abbey itself played in Bentham's work. Did Place's report of the desolation of much of the Devonshire countryside encourage their ideas on education and representative democracy, and did Ford Abbey keep Bentham focused on the usefulness of religion in this life?

\section{Conclusion}

When Bentham left Ford Abbey towards the end of February 1818 he gave no indication that he would not return, in fact he states that he had every expectation of returning, but in the event he did not. In July 1818 Bentham began the final negotiations to end the lease, with a view to handing the Abbey back to Gwyn. ${ }^{157}$ Quite why Bentham gave up Ford Abbey is not clear; but in September 1818 Bentham wrote to Jean Baptiste Say: 'No more Ford Abbey. Divers circumstances concurred in preventing my keeping it any longer'. By the end of the year Bentham had also lost two of his oldest and dearest friends. Anne Romilly died after a short illness on 29 October 1818, and on 2 November 1818, inconsolable at the loss, Samuel Romilly killed himself. Their friends were deeply shocked at the death of the Romillys. ${ }^{158}$ James Mill wrote to Place:

I cannot tell you how much I have been affected by the dreadful tragedy in this family. When you and I saw them last year at Ford Abbey, and admired and loved them all, we should have declared that there were

\footnotetext{
${ }^{155}$ Letter 2375 to John Herbert Koe, 1 January 1817, ibid., ix. 3. For example, Bentham produced an average of eleven/twelve manuscripts per day on 25, 26, 27 January 1817, and by February was writing on the backs of cancelled folios.

${ }^{156}$ Although Bentham was still writing what he intended as an introduction or postscript: Letter 2378 to John Herbert Koe, 25 January 1817, ibid., ix. pp. 7-8.

${ }^{157}$ See correspondence between Bentham and Gwyn, ibid., ix, as index.

${ }^{158}$ Bentham claimed he never dined away from home after Romilly's death, see Letter 2930 to Richard Rush, 12 October 1822, ibid., xi. p. 164.
} 
more elements of happiness mixed up in their lot than in that of almost any other human beings we knew-and yet how sudden the reverse! ${ }^{159}$

The respect and affection with which the friends regarded each other is evident from their writings. Romilly called Bentham his 'old and most valuable friend'. ${ }^{160}$ Bentham wrote: 'My acquaintance with Romilly commenced in 1784 or 5 [...] On my return from Russia, early in 1788, it ripened into intimacy, which continued without interruption or coolness till his death'. ${ }^{161}$ As well as these declarations of friendship, other evidence is provided by the excitement Bentham felt at the prospect of their visit to Ford Abbey. He mentioned their proposed visit in five letters to Koe, ${ }^{162}$ expressing his concern about subjects as diverse as reading matter and cutlery:

Have you any non-silver spoons that you could eat your broth with till the quality are come and gone which will be before the month is out? .. When quality are gone, the silver shall be honestly returned. ${ }^{163}$

Bentham wrote an account of their visit to Ford Abbey: ' both of them expressed themselves more pleased with the place than any body else that was ever here'. ${ }^{164}$ According to Bentham's account, Anne Romilly had made two different sketches of the Abbey, both of which Bentham felt were superior to others he had seen, and he dropped hints about copies, either printed or engraved. Given the deaths of both Samuel and Anne Romilly within fourteen months of their visit, the chances of the sketches surviving, and being engraved seemed slim, but in fact one of the sketches was engraved and published twelve years later, although Bentham seemed unaware of its appearance. In 1829 one of Anne Romilly's sketches, drawn by George Campion and engraved by Thomas Higham, was included in the second volume of a work entitled The History of Devonshire from the earliest times, ${ }^{165}$ and provides a fitting memorial to a happy time in the lives of the these friends.

\footnotetext{
${ }^{159}$ A. Bain, James Mill, p. 175.

${ }^{160}$ Memoirs of the Life of Sir Samuel Romilly, iii. p. 315.

${ }^{161}$ Letter 2527 to Francis Place, 6 December 1818,Correspondence $(C W)$, ix. p. 293.

${ }^{162}$ Letters 2401, 2403, 2405, 2411, ibid., ix. pp. 44, 45, 50, and 60.

${ }^{163}$ Letter 2412 to John Herbert Koe, c.6 September 1817, ibid., ix. p. 61.

${ }^{164}$ Letters 2416 and 2417, 29 and 30 September 1817, ibid., ix. pp. 65-71.

${ }^{165}$ Revd Thomas Moore, The History of Devonshire from the earliest period to the present, [...] Illustrated by a series of Views, drawn \& engraved under the direction of William Deeble, 3 vols., London, 1829-30, i. p. 472. Some details in the sketch can perhaps be confirmed. Bentham's statement
} 


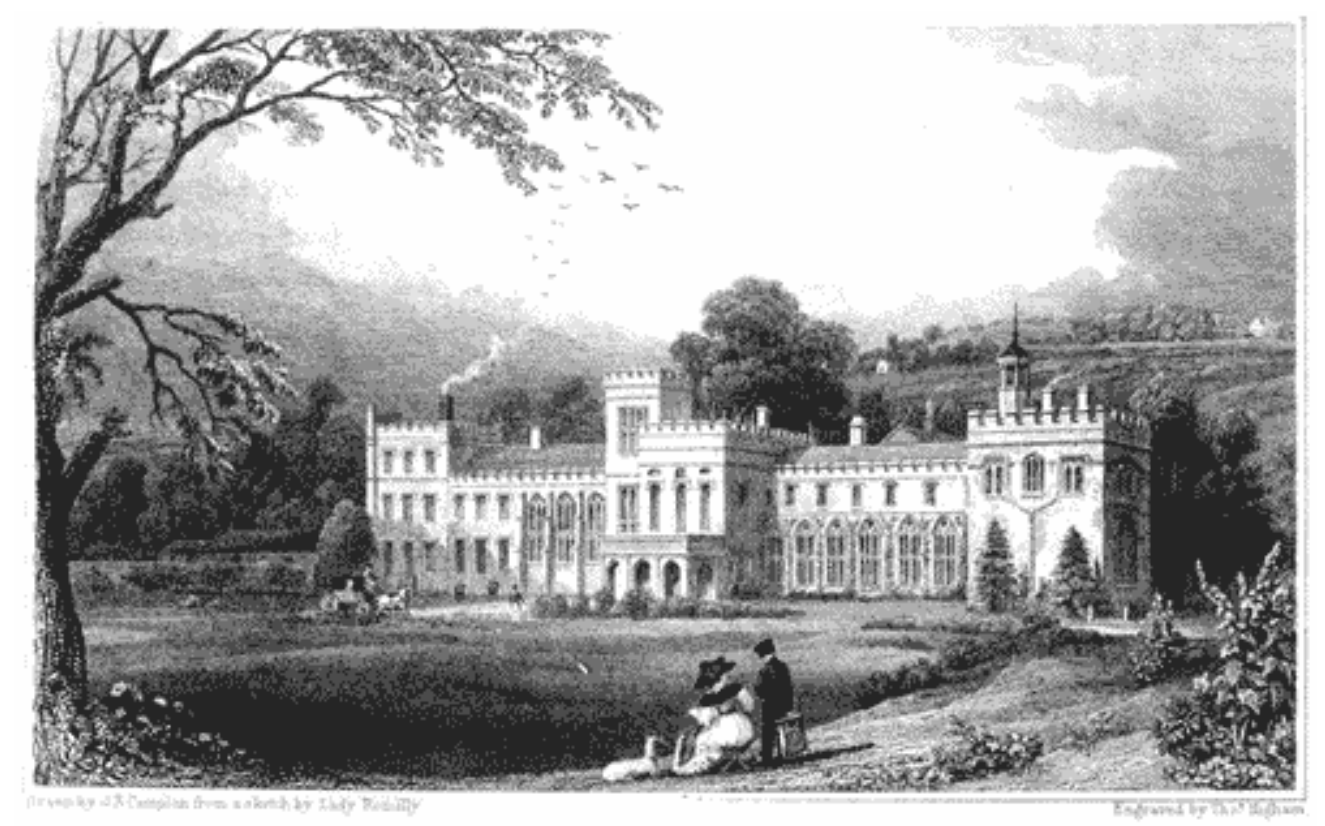

Figure 4. Ford Abbey, drawn by G.B. Campion from a sketch by Lady Romilly

Why was Bentham so happy at Ford Abbey? Certainly if we match the details of his stay at the Abbey to his own account of what promotes happiness or pleasure (and avoids pain), we can see that Ford Abbey provided Bentham with nearly all the sorts of pleasure he itemised in 1780: pleasures of the senses, of wealth and possession, of skill, of amity, of benevolence, of memory, of the imagination, of association, and of expectation. ${ }^{166}$ Even employing Bentham's felicific calculus for evaluating pleasureintensity, duration, certainty or uncertainty, propinquity or remoteness, fecundity, purity, extent-it is hard not to calculate that at Ford Abbey Bentham ought to have been happy, and from the evidence we have, we may conclude that he was. As we have seen Paley's work on St Paul was keenly sought by Bentham while working on Not Paul but Jesus at Ford Abbey. Another of Paley's work, it has been suggested, was a spur to the publication of Bentham's An Introduction to the Principles of Morals and Legislation in 1789 in response to the appearance of William Paley's The

to Gwyn that 'every bit of a wall that would receive a fruit tree has received one' appears corroborated by the wall to the left of the house which does have fruit trees espaliered along it (Correspondence, ix. 229), and Place's statement that the Romillys arrived with 'their carriage and servants' (Autobiography of Francis Place, p. 250) may be confirmed by the inclusion of a carriage and at least two servants in the engraving, though whether these items (and a portrait of herself in the act of drawing) were included in Anne Romilly's sketch cannot be confirmed.

${ }^{166}$ See Bentham, An Introduction to the Principles of Morals and Legislation, ed. J.H. Burns and H.L.A. Hart, London, $1970(C W)$, pp. 42-5. The work was printed in 1780 and published in 1789. 
Principles of Moral and Political Philosophy which appeared in $1785 .{ }^{167}$ Like Bentham, Paley argued that pleasure varied according to the man, his tastes, and circumstances, and that therefore happiness had to be assessed against variable criteria, but, unlike Bentham, he did not enumerate the means by which it could be calculated. For Paley happiness was neither to be found in the pleasures of the senses, nor absence from pain, labour, nor care, nor in the realization of wordly ambition: all of which he considered temporary. ${ }^{168}$ For Paley happiness came in more durable forms to be measured by continuance and intensity. He divided happiness into four categories: ${ }^{169}$ the first being the exercise of social affections, an opportunity for which was certainly provided by Ford Abbey (and Paley adds the want of which 'may be imputed to peevishness of monks, and of such as lead a monastic life'); and the second, the exercise of the faculties, of body or mind, of 'men in any pursuit which interests them': and here Bentham would probably have agreed with his old adversary, when Paley wrote that such pleasures might be: 'the writing of a book, [...] the laying out of a garden, the digging of a fish-pond-even the raising of a cucumber [...]'.

\footnotetext{
${ }^{167}$ Bentham, An Introduction to the Principles of Morals and Legislation, 1996, editorial introduction, p. li-lvi.

${ }^{168}$ Implicit in the theologian Paley's work, and in direct opposition to Bentham's, is of course the view that the earnestness of any endeavour keeps man focused on the future happiness in God.

${ }^{169}$ W. Paley, The Principles of Moral and Political Philosophy, London, 1785, Book I, Chapter VI. Human Happiness. The final two categories being: a prudent constitution of the habits, and in health.
} 


\section{Illustrations}

1. Ford Abbey 1817. A plan of the Abbey drawn by Francis Place, and sent to his wife Elizabeth:.see BL Place Papers, 35,143 fo. 286r. Reproduced by permission of The British Library.

2. Ordnance Survey map, 25 inch, Somerset Sheet 92(9), 1889.

3. Plan of the first floor room at Ford Abbey where Bentham, Mill, and Place worked: see BL Place Papers, 35,143 fo. 281v. Reproduced by permission of The British Library.

4. Ford Abbey Devon, drawn by G.B. Campion from a sketch by Lady Romilly in Thomas Moore, The History of Devonshire from the earliest period to the present, [...] Illustrated by a series of Views, drawn \& engraved under the direction of William Deeble, 3 vols., London, 1829-30. The engraving of Ford Abbey appeared in the first volume of the work entitled Biography, opposite page 472 .

\section{(c)(1) $\Theta \Theta$}

This work is licensed under the Creative Commons Attribution-NonCommercial-NoDerivs 2.0 UK: England \& Wales License. Under the terms of this licence, you are allowed to copy and distribute this work, but must give the original author credit. You not use this work for commercial purposes, nor alter or transform this work, without prior permission from the author. To view a full copy of this licence, visit: http://creativecommons.org/licenses/by-ncnd/2.0/uk/ or send a letter to Creative Commons, 444 Castro Street, Suite 900, Mountain View. 